\title{
ORB PLUS CONE-WEBS IN ULOBORIDAE (ARANEAE), WITH A DESCRIPTION OF A NEW GENUS AND FOUR NEW SPECIES
}

\author{
By Y. D. Lubin, ${ }^{1}$, B. D. Opell, ${ }^{2}$, W. G. Eberhard, ${ }^{3}$ \\ AND H. W. LEVI ${ }^{4}$
}

\section{INTRODUCTION}

Spiders of the genus Uloborus (Uloboridae) characteristically spin horizontal orb-webs with a sticky spiral of cribellar silk. We describe here the webs of $U$. conus, $U$. albolineatus, $U$. bispiralis, $U$. \#2072, U. trilineatus, and Conifaber parvus. which are modifications of this basic uloborid orb-web form and include cones composed of regular arrays of threads beneath the orbs' lower faces. The web building and prey capture behaviors of $U$. conus (observations of YDL) are also described, and descriptions of Conifaber parvus new genus, new species and the new species $U$. conus, $U$. albolineatus, and $U$. bispiralis are provided (by $\mathrm{BDO}$ ).

\section{Study Sites AND Methods}

Uloborus conus was found at three localities in Papua New Guinea: 1) in lowland wet forest, Gogol Forest Reserve near Madang, Madang Province, 2) in a Pandanus swamp (freshwater) and a mangrove swamp (brackish) at Buso, Morobe Province, and 3 ) in the understory of klinki pine (Araucaria hunsteinii) plantations at $1200 \mathrm{~m}$ elevation in McAdam Memorial Park near Wau, Morobe Province. Webs were built about 0.5 to $2.0 \mathrm{~m}$ above the ground in gaps formed by the uppermost, generally vertical branches of small shrubs and saplings. They were always found in humid, shaded

1. Smithsonian Tropical Research Institute, Apartado 2072, Balboa, Panama and Department of Zoology, University of Florida, Gainesville, Florida, 32611.

2. Department of Biology, Virginia Polytechnic Institute and State University, Blacksburg, Virginia 24061.

3. Smithsonian Tropical Research Institute and Escuela de Biología, Universidad de Costa Rica, Ciudad Universitaria "Rodrigo Facio", Costa Rica.

4. Museum of Comparative Zoology, Harvard University, Cambridge, Massachusetts 02138 .

*Manuscript received by the editor September 25, 1981. 
locations. Several individuals were kept and observed in an insectary at the Wau Ecology Institute (WEI).

Uloborus albolineatus and $U$. bispiralis were found on the Gazelle Peninsula, East New Britain (ENB), Papua New Guinea. The webs of $U$. bispiralis were observed on the Lowlands Agricultural Experimental Station (LAES) at Kerevat, ca. $100 \mathrm{~m}$ elevation, in cocoa plantations and in secondary growth lowland forest and near Malasat (ENB) at ca. $600 \mathrm{~m}$ elevation. One web of $U$. albolineatus was observed at LAES in secondary-growth forest along a river.

A single mature female of Uloborus \#2072 (numbers refer to specimen numbers placed in vials) was found (by WGE) near Dandeli, Karnataka, India, in the foliage of a bush growing in a teak forest. Uloborus trilineatus is common in undergrowth of gallery forest in eastern Colombia where WGE worked extensively. The webs described here were found at Finca Chenevo, about $20 \mathrm{~km} \mathrm{SW}$ of El Porvenir, Meta, and Finca Mozambique, about $15 \mathrm{~km} \mathrm{SW}$ of Puerto Lopez, Meta. Conifaber parvus was also found at Finca Mozambique (by WGE) where it occurred in periodically flooded forest but not in surrounding savanna.

Webs were first dusted with cornstarch or talcum powder using either the method described by Eberhard (1977a) or Carico's (1977) modification of this method, and then measured and photographed. All specimens mentioned in this paper are deposited in the Museum of Comparative Zoology.

\section{OBSERVATIONS}

\section{Uloborus conus*}

\section{The Web}

The web of $U$. conus has three parts: the inner orb, the rim, and the cone (Fig. 1). The inner orb and rim are in nearly the same plane and are more or less horizontal. The inner orb consists of a closed hub, radii and a few loops of non-sticky spiral, while the rim has several loops of sticky, cribellar spiral which end where the rim radii join those of the inner orb. Rim radii are continuous with those of the cone, and those of the inner orb are attached to them. Cone radii are attached in groups of two or three to a central guy thread which

*This is a new species decribed below. 

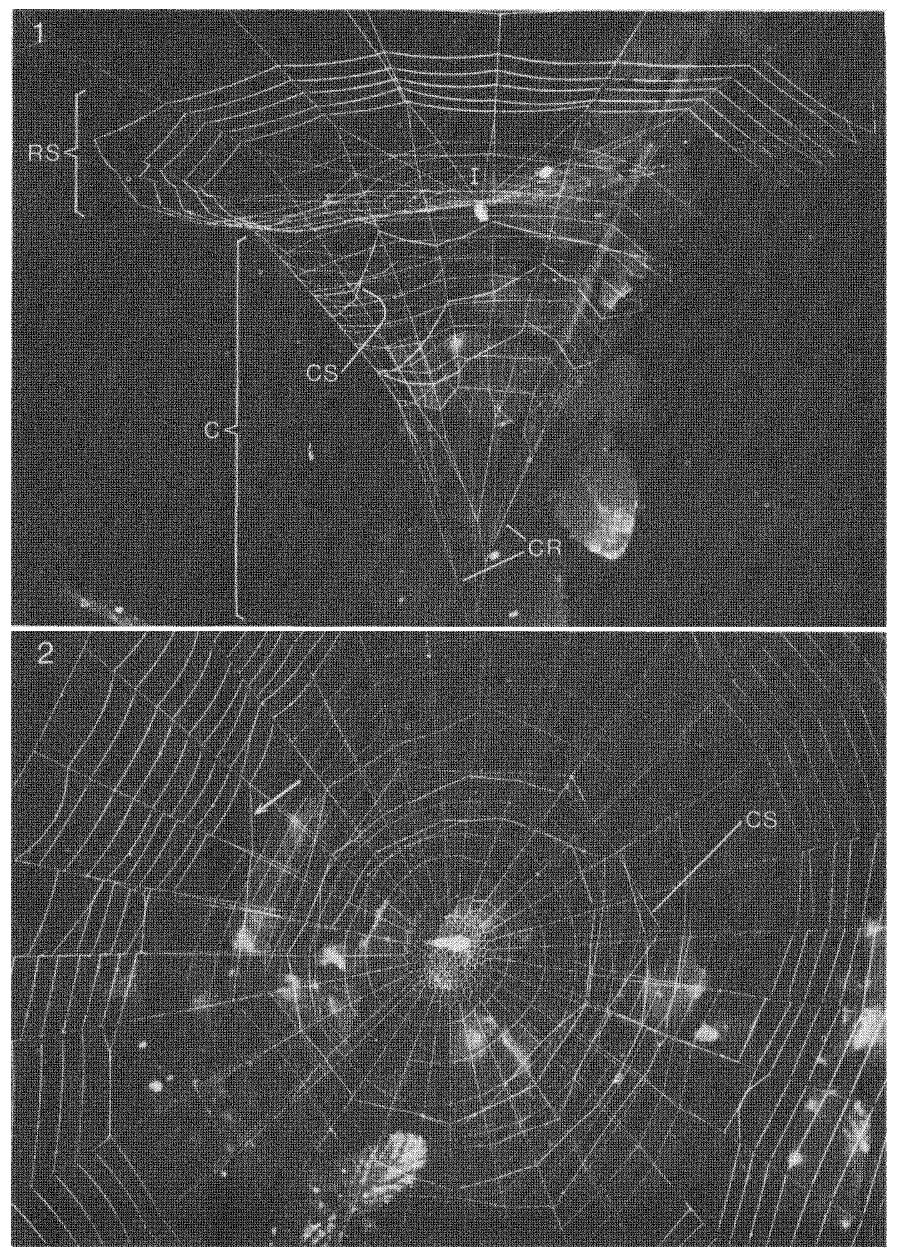

Figures 1-2. Web of Uloborus conus. 1. Side view showing the rim sticky spiral (RS), inner orb (I), cone (C) with jagged sticky spiral (CS) on a framework of radii and non-sticky spiral, and cone radii (CR) converging toward a central guy thread. Note that 2-3 cone radii are attached together to form one thread which attaches to the cone guy thread, and that these attachments are dispersed along the guy thread so that there is no single apical point to which all cone radii attach. 2. Top view showing typical Uloborus-type hub and non-sticky spiral of the inner orb. The cone with its jagged sticky spiral (CS) is seen through the plane of the orb. Note the gap between the non-sticky spirals of the cone and inner orb on the one hand and the rim sticky spiral on the other. The cone sticky spiral can be seen as a continuation of the rim spiral (arrow points to beginning of cone sticky spiral). 
is in turn attached distally to a leaf or branch. The cone has a nonsticky spiral and a few irregularly-spaced, jagged turns of cribellar silk. This jagged sticky spiral is a continuation of the innermost sticky spiral loop in the rim (Figs. 2, 4).

The hub of the inner orb (Fig. 2) is similar to that of other uloborid orbs, e.g. U. diversus (Eberhard, 1972), and its spiral continues outward to form the non-sticky spiral of the inner orb. There is always a large gap between the last turn of this spiral and the innermost loop of sticky rim spiral (Figs. 1, 2).

Sticky spiral loops in the rim are more tightly spaced than are either the non-sticky spiral loops of the inner orb and cone or the cone's sticky spiral. The outermost loop of rim spiral often follows a zigzagging path, with some segments of the sticky silk found on the radii (Figs. 2, 3). This zigzagging was more pronounced in some webs than in others and was generally most evident on the side of the orb which was larger (the orbs were rarely perfectly symmetrical).

Variations on this basic pattern were seen. Webs of immatures frequently had only a narrow rim, sometimes with only a single loop of sticky spiral. Some webs had a few loops of sticky spiral on the inner orb, with the non-sticky spiral left intact (Fig. 4). Webs of two adult females and several immatures had thin linear stabilimenta at their inner hubs. Adult males were found sitting on webs similar to those of immatures, but it was not determined if these were of their own construction. Adult males did not build webs in captivity.

\section{Web Building Behavior}

Web building by two adult females was observed from start to finish and various stages of web construction were seen on four other occasions. Durations of different stages of construction were noted for one of the adult females. Web construction began late at night or in early pre-dawn hours. The inner orb and cone of the old web were probably removed early in the night, but this behavior was not observed. One WEI female was found sitting at the center of a rudimentary web consisting of a partly collapsed rim and a few radii, and had a ball of silk in her mouthparts which shrank visibly as it was (presumably) ingested. This spider removed the rest of the rim and added the material to the ball of silk in her chelicerae before building the new web. Reusing frame threads from the previous web, the spider began construction by laying new radii. 

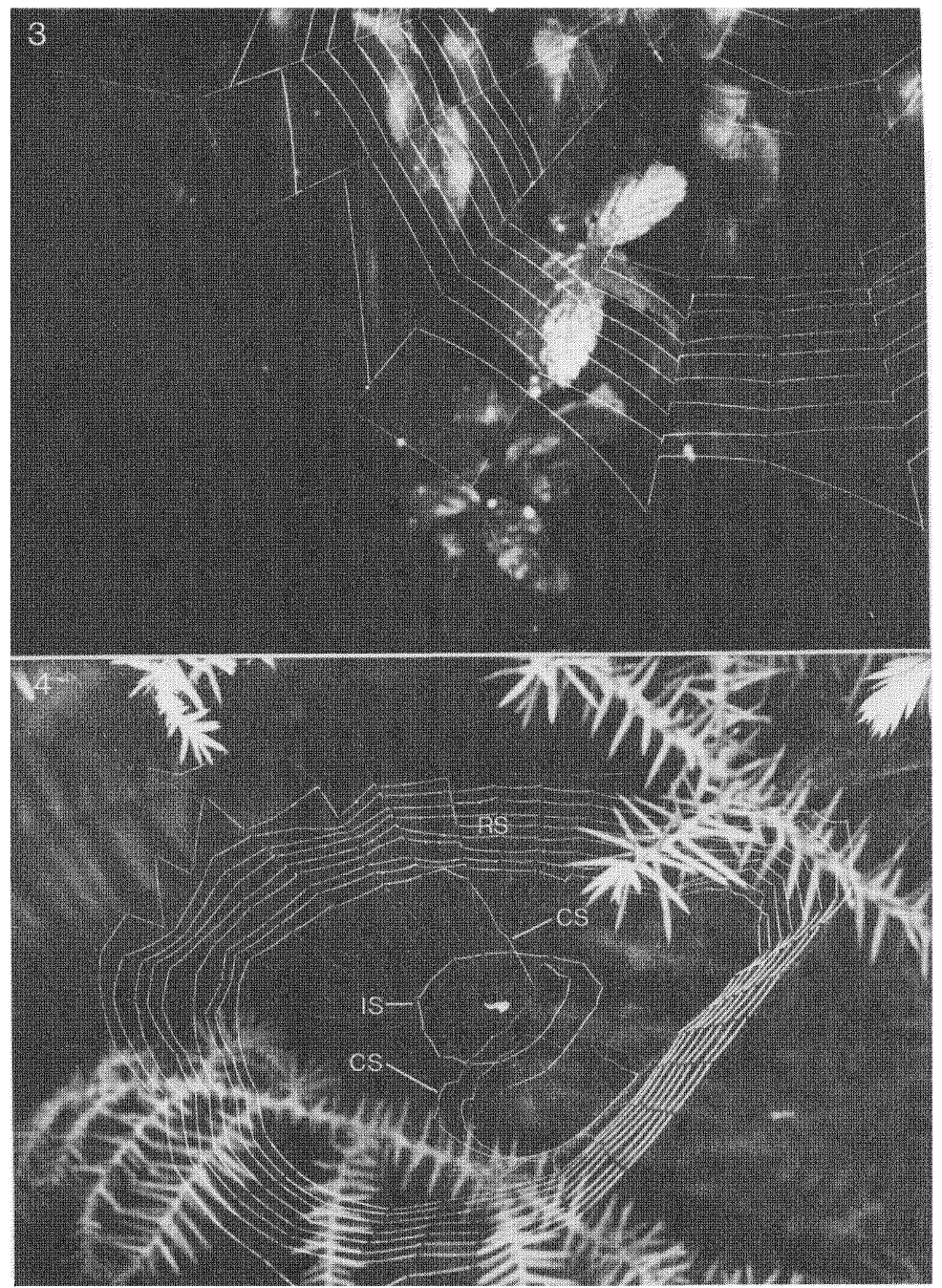

Figures 3-4. Web of Uloborus conus. 3. Detail of first (outermost) loop of rim sticky spiral showing zigzag path with sticky silk laid directly on the radii. 4. Top view of web with $1 \frac{1}{2}$ loops of sticky spiral (IS) in the inner orb (IS). Also visible is the cone sticky spiral (CS) continuing in from the rim spiral (RS) and the zigzag outer loop of rim sticky spiral. 
Radii and non-sticky spiral were laid as in $U$. diversus (Eberhard, 1972) and their construction lasted 5 and 1.5 minutes, respectively. Radii were laid by walking out from the hub on an existing radius with a dragline, attaching the dragline to a frame thread, and then doubling it by walking back to the hub with another dragline. At the hub the dragline was attached to a succession of adjacent radii (forming the closed hub spiral) before the next radius was laid. When most of the radii were completed, the spider continued the hub spiral outward to form the non-sticky spiral, laying occasional "tertiary radii" (Le Guelte, 1966) during the process. This non-sticky spiral did not reach the frame threads.

At the start of the sticky spiral even very faint light falling on the spider caused her to cease spinning and bounce up and down on the web. Consequently, observations of sticky spiral construction were made only sporadically, using indirect lighting. The first (outermost) loop of non-sticky spiral was completed in 13 min. During sticky spiral construction the spider reversed directions five times in the larger part of the web. The sticky spiral was attached to each radius that it crossed, and the spider broke non-sticky spiral loops as she laid the sticky spiral. One immature female was observed laying a zigzag outer loop of sticky spiral. The sequence of attachments of the cribellar silk to produce the zigzag loop (Fig. 5a) was distinct from that involved in laying the normal sticky spiral loops (Fig. 5b).

After meticulous, slow sticky spiral construction, which in one case lasted $3 \mathrm{hrs}$. $6 \mathrm{~min}$., the spider suddenly began spinning out cribellar silk in a rapid and seemingly reckless fashion while moving inward toward the hub at an angle of about $25^{\circ}$ to the last turn of the regular sticky spiral (Figs. 2, 4). After completing half a loop, the spider reversed direction and continued spiralling toward the hub, laying a jagged and irregularly spaced sticky spiral. The jagged spiral was attached to only a few radii, crossing 3-7 radii and, in some cases, several non-sticky spiral loops between attachments. The non-sticky spiral was left intact. This entire phase was very rapid and in one case the four jagged loops were completed in just 6 min. This jagged spiral was to become the sticky spiral of the future cone.

After completing the cone sticky spiral, the spider moved to the hub and slowly turned in a circle, pulling on successive radii with the first legs. After 2 min. she went out to the end of a radius and 

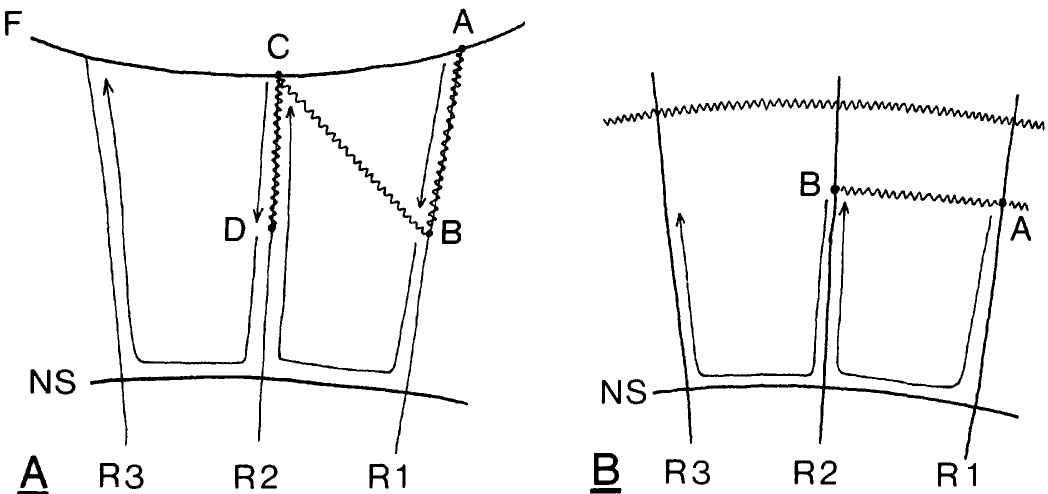

Figure 5. Construction of $U$. conus web. (a) Sequence of attachments of sticky silk to produce the outer zigzag loop of rim sticky spiral. The spider started at the junction of the radius (R1) and frame thread (F), attaching the cribellar thread at point $A$, walked along $R 1$ toward the hub and attached the cribellar thread at point B, about half way between the frame thread and outer loop of non-sticky spiral (NS). The spider then continued inward along R1, combing out cribellar silk, reached the non-sticky spiral and ran rapidly across it and $2 / 3$ of the way out on $R 2$ without combing out additional silk. It then continued to walk out on R2, combing out cribellar silk and attached the thread at point $C$, the junction between $R 2$ and the frame thread. The sequence was then repeated, walking in along $\mathrm{R} 2$, attaching cribellar thread at point D, etc. (b) Sequence of attachments of cribellar silk to produce the normal sticky spiral. The spider attached cribellar thread at point $A$ on radius $R 1$, walked in on $R 1$, combing out cribellar silk, until it reached the temporary, non-sticky spiral loop (NS), then ran along the non-sticky spiral and out on radius $\mathrm{R} 2$ without combing out cribellar silk and attached the cribellar thread to $\mathrm{R} 2$ at point $\mathrm{B}$.

dropped from it to a leaf below, attached her dragline to the leaf, and went back up the dragline and across the web to its hub on a radius, attaching the new dragline from the leaf to the hub. This formed the central guy thread of the cone. The spider then went down the guy thread, broke it, reattached it to a different point on the leaf, and then returned to the hub. By this time the hub was already drawn down under tension, and the web formed a shallow cone. The cone was then elongated by cutting radii at their attachment to the hub, lowering their tension and then attaching them to the central guy thread by the sequence of behaviors shown in Fig. 6a, b. 
A.
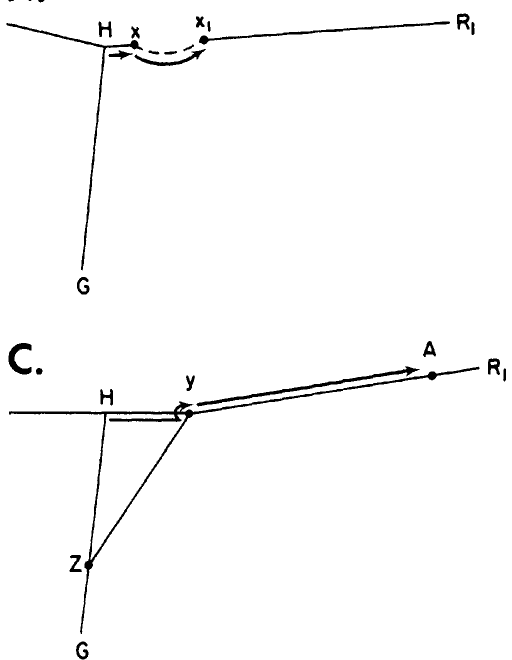

B.
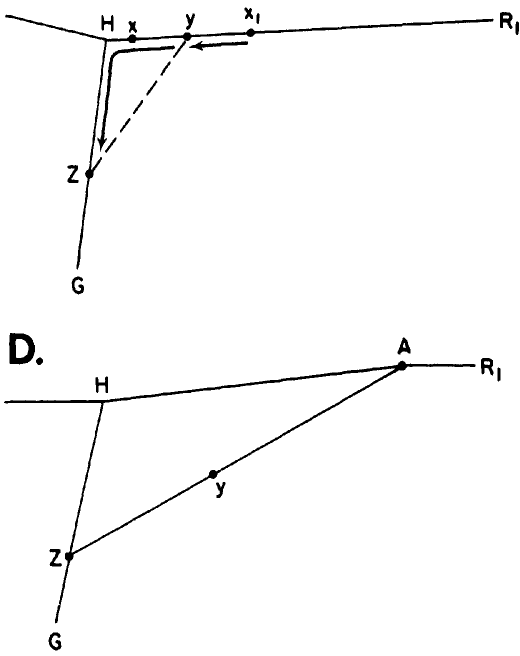

Figure 6. Construction of $U$. conus web. Sequence of thread attachments in forming the cone (web viewed from the side). Arrows indicate direction of movement of the spider. Dots are points where attachments were made or broken. (a) The spider went to point $\mathrm{X}$ on radius $\mathrm{R} 1$ at the edge of the hub, cut the radius, attached its dragline to the inner broken end and then let out additional dragline as it faced away from the hub. This was then attached to the outer broken end which had now moved to point $X_{1}$. Usually adjacent radii were also broken and attached to radius $R_{1}$ at point $\mathrm{X}_{1}$ (see also Fig. 1). (b) The spider then walked back toward the hub to point $\mathrm{Y}$, attached a dragline, ran to the hub and down the central guy thread (G), attaching the dragline at point $\mathrm{Z}$. Radius $\mathrm{R} 1$ was thus pulled down toward the apex of the cone to form the cone radius $\mathrm{YZ}$ while the thread $\mathrm{HY}$ formed a temporary inner orb radius. (c) To move the temporary inner orb radius up on the cone, the spider walked out on temporary radius $\mathrm{HY}$ and broke it at its attachment to the cone at point $Y$. The spider then attached a dragline to the broken end and walked out on radius $R 1$, reattaching it at point $A$ at the inner edge of the rim sticky spiral.

(d) The completed cone radius is indicated by line $\mathrm{AZ}$ and the new inner orb radius by line HA. The section AY of the cone radius bears the cone sticky spiral. The upper portion of the guy thread $(\mathrm{HZ})$ was absent in the completed web, but it is not known when it was removed.

After forming the cone, the spider cut most of the temporary inner orb radii, thus collapsing the hub and leaving only a bit of silk to which a few temporary radii were attached. The spider then began replacing these temporary inner orb radii and at the same time completing cone formation by incorporating into the cone the 
section of the original orb containing the jagged sticky spiral (Fig. 6c, d). This stage followed initial cone formation without interruption, and it was difficult to determine when cone building ended and replacement and construction of new inner orb radii began. The spider went out to the cone along a temporary radius, broke the attachment to the cone and attached her dragline to the inner end of the temporary radius, then carried the radius upward by walking along radii and non-sticky spiral loops on the inner surface of the cone, and finally reattached it at or just inside (below) the innermost loop of the rim sticky spiral. She then walked back to the hub on the new radius, thereby doubling the thread. Upon reaching the center, she made attachments to form a new hub. The upper portion of the guy line was absent in finished webs, but it was not determined how it was removed.

Additional new inner orb radii were constructed in much the same manner as "normal" orb radii. The spider went out on an existing radius (or temporary radius) with a dragline, reached the cone non-sticky spiral, walked across it to the next cone radius, attached the dragline to the cone radius just below (inside) the rim spiral, and return to the hub on the new radius (doubling it). Consecutive radii were always laid with angles of more than $90^{\circ}$ between them, perhaps serving to reduce differences in tension on all sides of the orb (Eberhard, 1981).

The last stages of web building, beginning with attachment of the dragline and ending with completion of the inner web, lasted 23 $\min$.

\section{Resting Postures}

The spider normally sat under the hub with legs I and II slightly flexed and holding separate radii. When disturbed, the spider adopted a cryptic posture with legs I and II held together and flexed and legs III and IV pressed close to the body (Figs. 2, 4). This posture was adopted either at the hub or under a short "dragline" thread beneath the hub, which was attached to the hub at one end and to a radius at the other. When disturbed repeatedly, or when sunlight struck the web and made it visible, the spider dropped from the hub onto the dragline thread and bounced up and down on it. Spiders also bounced while wrapping prey and sometimes while going out to attack an insect or upon returning to the hub. This 
bouncing may be an anti-predator behavior similar to the bouncing flight of craneflies and the rapid vibrating of opilionids and pholcids.

\section{Prey Capture Behavior.}

Successful captures of five fruitflies (Drosophila-size), one $4 \mathrm{~mm}$ long dolichopodid fly, one unidentified $1 \mathrm{~mm}$ fly, three 3-4 mm ants, and one $5 \mathrm{~mm}$ lepidopteran larva were observed (by YDL). Of these, seven were trapped in the rim and three in the cone. All but one sequence conformed to the description given below. Like other uloborids (Marples, 1962; Eberhard, 1969; Lubin et al., 1978) $U$. conus and $U$. bispiralis immobilize all insects by wrapping in silk. Spiders ran out to the cone on an inner orb radius to reach insects trapped in the rim sticky spiral, squeezed through the cone (often turning sideways to do so) and continued out onto the undersurface of the rim. If an insect was trapped on the cone sticky spiral, the spider went through the cone and ran down the outer surface of the cone. Upon reaching the insect, the spider often tapped it with legs I, turned $180^{\circ}$ so that it faced the hub (or upward on the cone) and began to wrap. Initially the prey was wrapped from a distance by throwing sheets of silk backwards with legs IV. Later the spider moved into contact with the prey and held it with legs II and III while wrapping. The spider interrupted wrapping to cut sticky spiral attachments, then cut the inner radius attachment (toward the hub) and continued to wrap while holding the end of the radius with one leg I. Finally, the outer (distal) end of the radius was cut and the prey was held free of the web in legs II and III while the spider hung from the broken radius by legs I, bridging the gap with its body, and wrapped the prey with legs IV while rotating it occasionally with the palps or legs.

All prey were carried to the hub in the palps (with the aid of the chelicerae), held "overhead" in characteristic uloborid fashion. After transferring the prey package from the legs to the palps, the spider attached a dragline to the distal end of the broken radius and then to the proximal end, thus closing the gap. At the hub the spider again transferred the prey from the palps to legs II and III and wrapped it while hanging from the dragline thread beneath the hub. In most instances the dragline thread appeared to be broken and the spider spanned the gap with its body. 
Prey Capture Sequences With Different Prey Types.

The only case not conforming to this description was that of a fruitfly caught on the inner orb; the spider wrapped it, secured it by reattaching it to the radius and fed on the prey in situ.

$U$. conus rejected or ignored a number of insects offered as prey. Five small orthopteran nymphs 3-4 mm long (probably newly emerged) where given to adult females and all were rejected. On two occasions, the spiders approached and tapped the insects with legs I and then returned to the hub. In other instances the spider pulled the radii in the direction of the orthopteran, shook the web and then ignored it. The same individuals readily attacked fruitflies offered as prey after the orthopterans. Fruitflies were not attacked on three occasions when they were offered while the spider was already wrapping a prey or feeding at the hub. Two ants (Anopolepis longipes, $4 \mathrm{~mm}$ long) were rejected under the same circumstances.

Sequences With Multiple Prey.

On six occasions spiders feeding at the hub attacked second or third prey thrown into their webs. These included two ants, two fruitflies, a dolichopodid fly and an unidentified small fly. On all but one occasion the spider carried the first prey in its palps as it ran out to attack the second. In one instance a spider that had been wrapping the first prey at the hub attached this insect to a dragline thread below the hub before going out to attack the second insect.

The second prey was immobilized in the same manner as the first, but rather than cut this insect out and carry it to the hub, the spider secured the second prey at the capture site and returned to the hub to resume feeding on the first prey. While performing immobilization wrapping, the spider usually broke the radius attached to the prey on the inner side (toward the hub), but not on the outer side. Before leaving it at the capture site, the spider reattached the prey to the broken end of the radius, thus securing it at both ends.

\section{Eggsac and Eggsac Web.}

The eggsac of $U$. conus is about $8 \mathrm{~mm}$ long by $3 \mathrm{~mm}$ wide, with angular projections along the edges (Fig. 7). It is suspended in an eggsac web on a strengthened radius of a former web, where the hub of the inner orb had been. The web is similar to those of $U$. diversus (Eberhard, 1969) and Miagrammopes sp. near unipus (Lubin et al. 1978) and consists of frame threads, a few radii and one or more 
zigzag loops of sticky silk, with some sticky silk laid directly on the radii. The radii are attached to the main eggsac radius or to the eggsac itself. One female had a three-dimensional eggsac web consisting of a rudimentary cone and inner orb radii (Fig. 7) with sticky silk in both the plane of the orb and the cone. Unlike the eggsac webs of Miagrammopes, these webs were retained both day and night. Insects that became entangled in the sticky threads were attacked in the usual manner.

Females guarded their eggsacs (one per female) until the young emerged (13 days for one eggsac). Newly emerged spiderlings remained on the eggsac web for one or two days, then moved away and constructed typical Uloborus-type "baby webs", consisting of radial threads connected by a thin sheet of very fine, non-sticky silk (Szlep, 1961; Eberhard, 1977b) without any cone. One immature, however, had an orb plus cone-web with a filmy "baby web" sheet where the rim sticky spiral would normally be found and also some "baby web" sheet on the cone. Structural spirals were present in the rim and inner orb; there was no sticky spiral.

\section{Uloborus bispiralis*}

The cone web of $U$. bispiralis (Fig. 8) is similar to that of $U$. conus in that the cone sticky spiral is continuous with that of the rim, and the outer loop(s) of rim spiral follow a zigzag path, with some sticky silk laid on the radii. Unlike webs of $U$. conus, the inner orb nonsticky spiral extends right up to the innermost (last) loop of rim sticky spiral and all webs had a few loops of sticky spiral in the inner orb. Most webs also had a thin, linear stabilimentum of white silk across the inner orb, with a spider-size gap at the hub.

Webs of juvenile females were similar in all respects to those of adults. None of the webs observed showed signs of repairs. Like those of $U$. conus, they are probably renewed daily. On one occasion only, a juvenile female was seen hanging inside the cone while an adult male fed on prey at the hub. Another adult male was observed sitting at the edge of an adult female's web and a third male was found sitting in a small cone-web (no sticky spiral was observed).

\footnotetext{
*This is a new species, described below.
} 

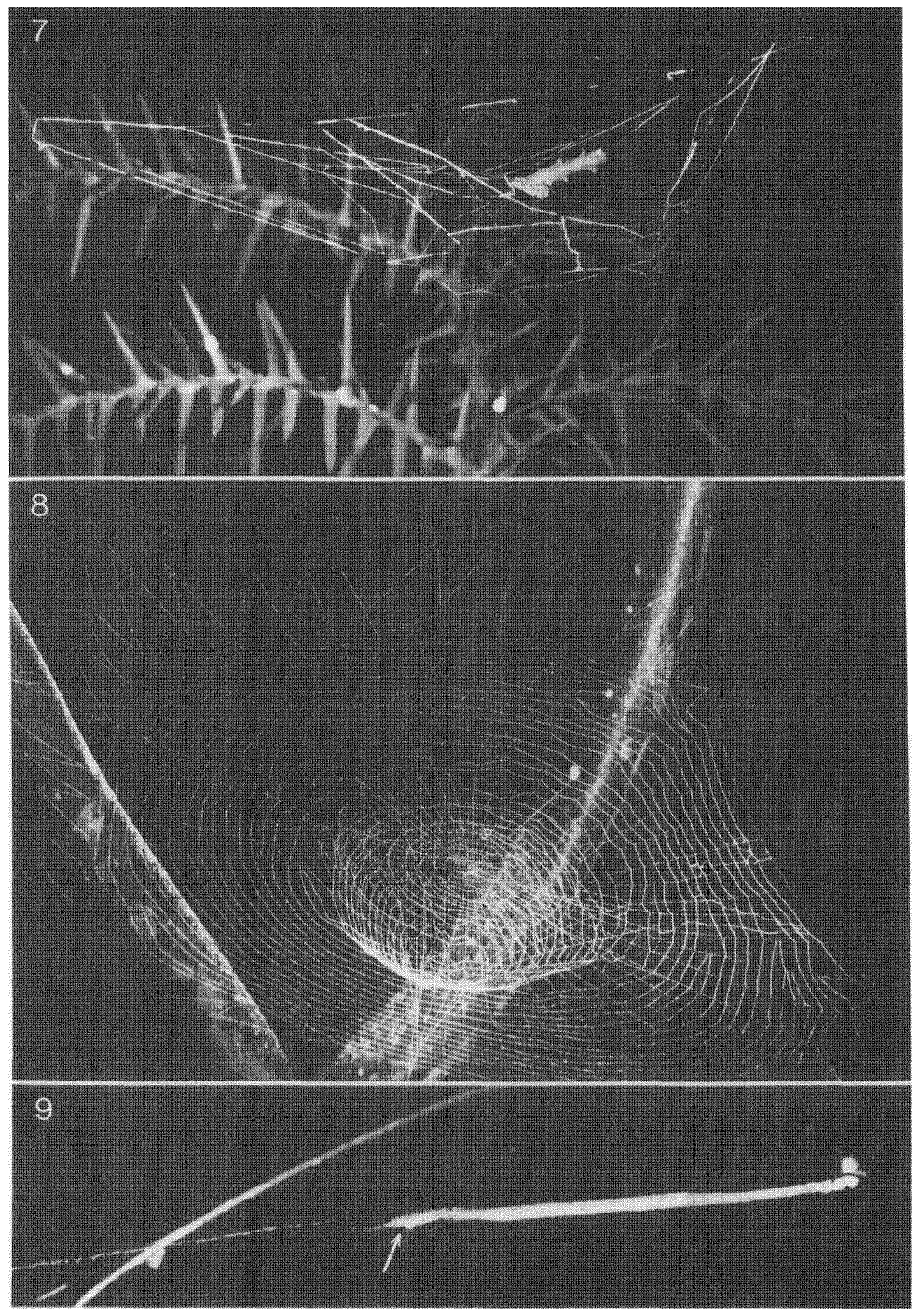

Figures 7-9. Uloborus. 7. Eggsac and three-dimensional eggsac web of Uloborus conus. The female spider can be seen sitting in a cryptic posture to the left of the eggsac. Sticky threads (heavy white lines) occur in the plane of the former orb and on the rudimentary cone. 8 . Web of Uloborus bispiralis. 9. Tubular eggsac of Uloborus bispiralis with female sitting in cryptic posture at one end of the eggsac (arrow). 
The long, tubular eggsacs of $U$. bispiralis (34-40 $\mathrm{mm}$ long and 1.5 $\mathrm{mm}$ wide) have no angular projections (Fig. 9) and resemble those of Miagrammopes (Lubin et al. 1978). They are suspended along the radius of a former web of which only a few radii and frame threads remained intact. There was no evidence of sticky silk in the four eggsac webs examined. Spiders sat in line with the eggsacs, with legs I and II extended forward and legs IV grasping the eggsac, and were reluctant to move even when prodded.

\section{Uloborus albolineatus*}

One individual of $U$. albolineatus was observed on a cone web similar to that of $U$. bispiralis. The rim spiral had one or two zigzag outer loops, and both the cone and inner orb had jagged loops of sticky spiral. The inner orb non-sticky spiral extended almost to the rim spiral. The female sat at the hub with legs I and II extended forward and held together and legs IV extended backward.

Uloborus sp. (2072)

Only a single web was seen. It consisted of a somewhat inclined orb ( $43^{\circ}$ with horizontal) with a cone underneath it which contained loops of sticky spiral (Fig. 10a, b). This web differed from those of $U$. Conus in having sticky spiral threads near the center of the horizontal orb (Fig. 10c) as well as near its edge, as well as having some of the "radial lines" of the cone attached directly to the frame of the orb while others ended on radii as in $U$. conus webs.

At the hub the spider sat in a "crouched" position (Fig. 10a) similar to that of Philoponella (Opell and Eberhard in prep.), and was reluctant to move away when disturbed.

\section{Uloborus trilineatus Keyserling}

Most of the many webs of mature and immature $U$. trilineatus individuals observed were typical, more or less horizontal orbs like those spun by other Uloborus species (e.g., Szlep, 1961; Wiehle, 1927; Eberhard, 1972). Webs of mature males were similar to those of newly emerged uloborid spiderlings (Szlep, 1961; Eberhard,

*This is a new species, described below. 


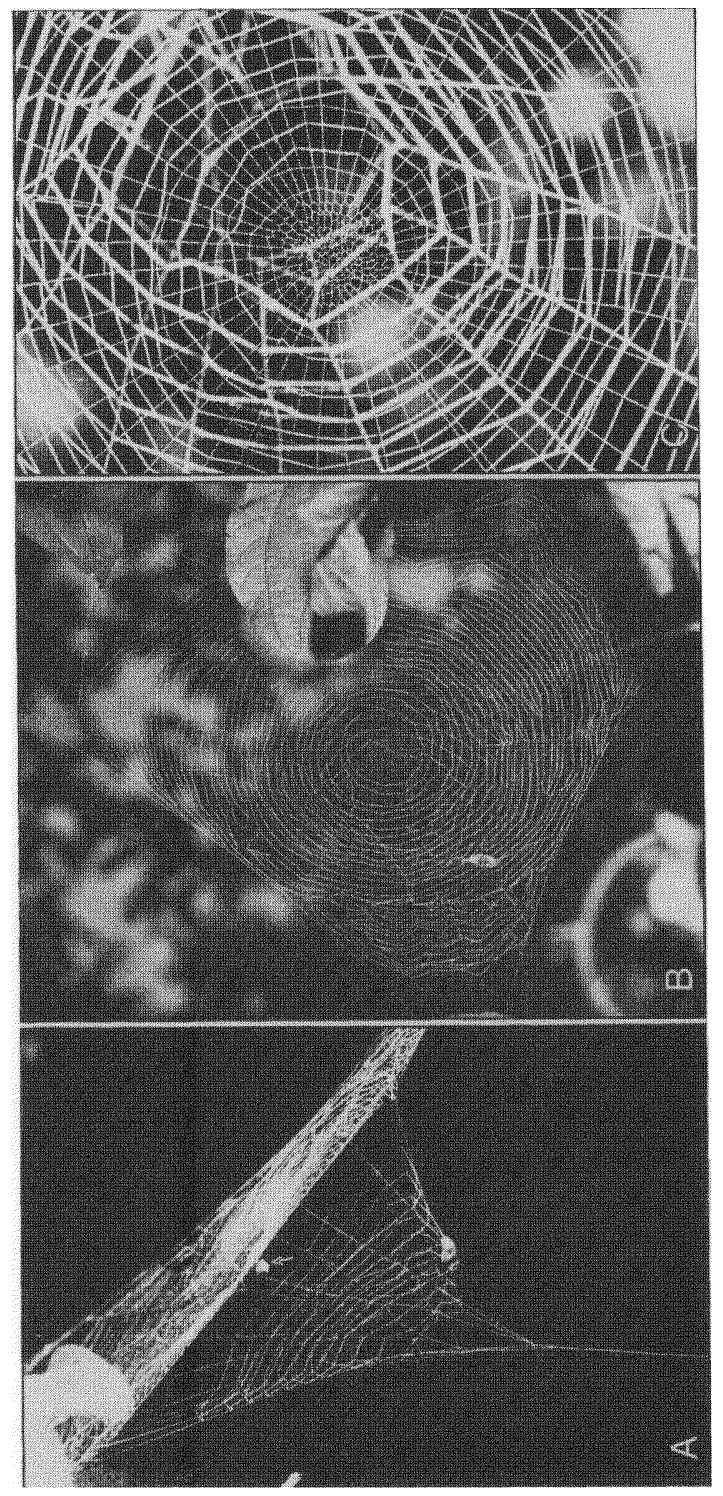

定

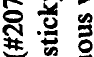

它

要

응

녕

응

을

3 造

용ㅎㅁ

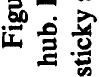


1977b). However, at both Finca Chenevo and Finca Mozambique one immature was found at the hub of a web like that shown in Figs. 11a, b. Each web consisted of a small, more or less horizontal orb which had only a non-sticky spiral. Below this was a cone which also had a non-sticky spiral. Only one of these spiders was collected, the other was left on its web, and the next day the web was deserted and an exuvium was found clinging to its hub. Identity of the collected immature specimen is not certain, but abundance of $U$. trilineatus at these sites plus the failure of extensive collecting of orb weavers to reveal similar species in these habitats indicates that these immatures were $U$. trilineatus.

\section{Conifaber parvus*}

This species was fairly common in a periodically flooded forest on Finca Mozambique. Only mature females were found with webs. The webs all had an "orb" similar or identical to those spun by most newly emerged uloborid spiderlings (Szlep, 1961; Eberhard, 1977b), having radii, hub, frames, and a non-sticky spiral as in typical orbs but lacking a sticky spiral and having instead a dense mat of very fine threads (so fine that in Figs. 12a, b they do not show up as individual threads, and one only sees the grains of cornstarch). Below this orb was a conical web consisting of radii which converged below to a single downward-directed line, and a more or less regularly spaced spiral, also of non-sticky silk. The hubs were often decorated with linear stabilimenta.

The spider crouched at the hub with its legs I folded ventrally in the typical Philoponella posture (Opell and Eberhard in prep.). Sometimes when a spider was disturbed she let herself fall from the hub and hung suspended inside the cone on her dragline and bounced actively there. On other occasions spiders bounced on their orbs.

Attack behavior was observed twice and seemed to be typical for uloborids. The spider turned to face away from the prey and threw silk over it with her legs IV, gradually cut it loose as she wrapped it, then held it with the palps and/or chelicerae as she reattached the ends of the broken radii, took it to the hub, and then resumed

\footnotetext{
*These are a new genus and species, described below.
} 

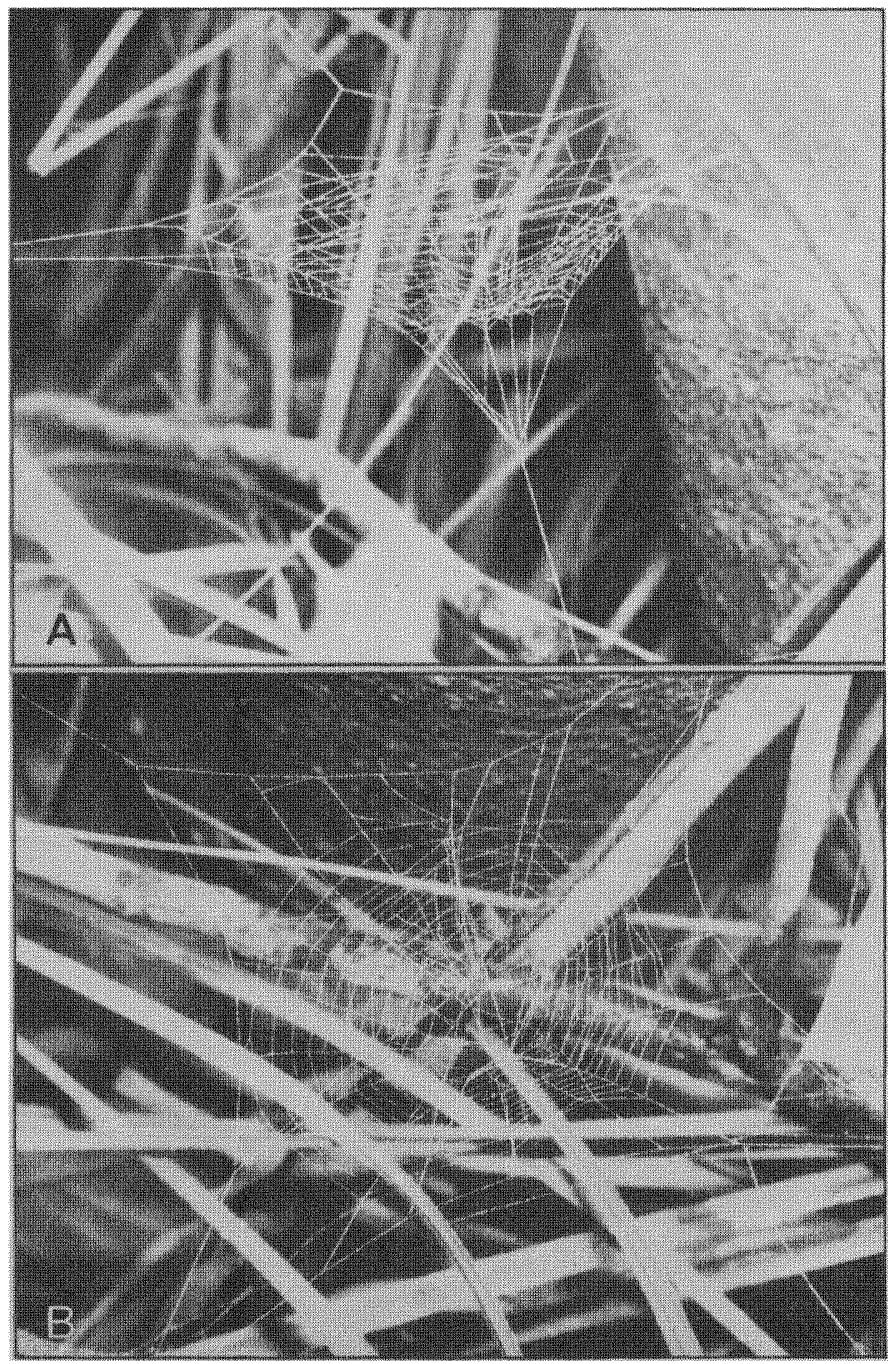

Figure 11. Web of penultimate female of Uloborus trilineatus Keyserling. A. Side view. B. Top view. Most (or all?) of the cone radii are attached to frame lines. The central area of the cone has fewer radii than the upper portion, and gives the impression of having been partially dismantled, perhaps during the process of being connected to the central thread as in $U$. consu. 
wrapping while hanging there by her spread legs I.

The eggsacs were different from those described for any other uloborid. They were pure white, 2-3 $\mathrm{mm}$ diameter spheres with projecting spikes, and resembled the heads of maces; they were suspended in the plane of the orb portion of the web on a radial line (Figs. 13a, b).

\section{Discussion}

While the webs of all five species are similar in having more or less horizontal orbs with cones below, the details are strikingly different. The cones of $U$. conus, $U$. albolineatus, $U$. bispiralis, and $U$. $\# 2702$ have a sticky spiral while those of $U$. trilineatus and $C$. parvus do not. In $U$. albolineatus, $U$. bispiralis, and $U$. sp. \#2702 both the outer (rim) and inner portions of the orb have sticky spirals, while in $U$. conus the main capture surface is the rim sticky spiral and only occasionally is a sticky spiral present in the inner orb. The "orbs" of Conifaber parvus have no sticky spiral, but the dense mat serves as a trapping surface, as in uloborid "baby webs". Orb-plus-cone webs of $U$. trilineatus have no sticky silk at all.

The function of the cone in webs of all four species is probably primarily defense of the spider at the hub against predators and parasites. The cone forms a "cage" of threads around the spider, and a defense function is suggested both by the fact that $U$. conus and Conifaber parvus drop from the orb and hang inside this cone when disturbed or when the web becomes visible in sunlight, and by the fact that construction of conewebs by $U$. trilineatus occurs only when the spiders are about to enter the particularly vulnerable moulting period. The sticky threads in the cones of $U$. conus and $U$. albolineatus and $U$. \#2702 sometimes trap prey (some $U$. conus webs have almost no other sticky lines), but the fact that the cones of $U$. conus, $U$. albolineatus, and $U$. bispiralis have only a few, irregularly spaced sticky spiral loops while those of $U$. trilineatus and $C$. parvus lack sticky threads suggests that prey capture is a secondary consequence rather than a primary function of at least some of the cones. Placement of sticky threads in cones could have evolved as an additional defense of the spider against predation or parasitism.

The uloborid cones resemble the barrier meshes made by the araneid Nephila maculata (Robinson and Robinson, 1973) at one or both sides of their more-or-less vertical orbs; in young $N$. maculata 


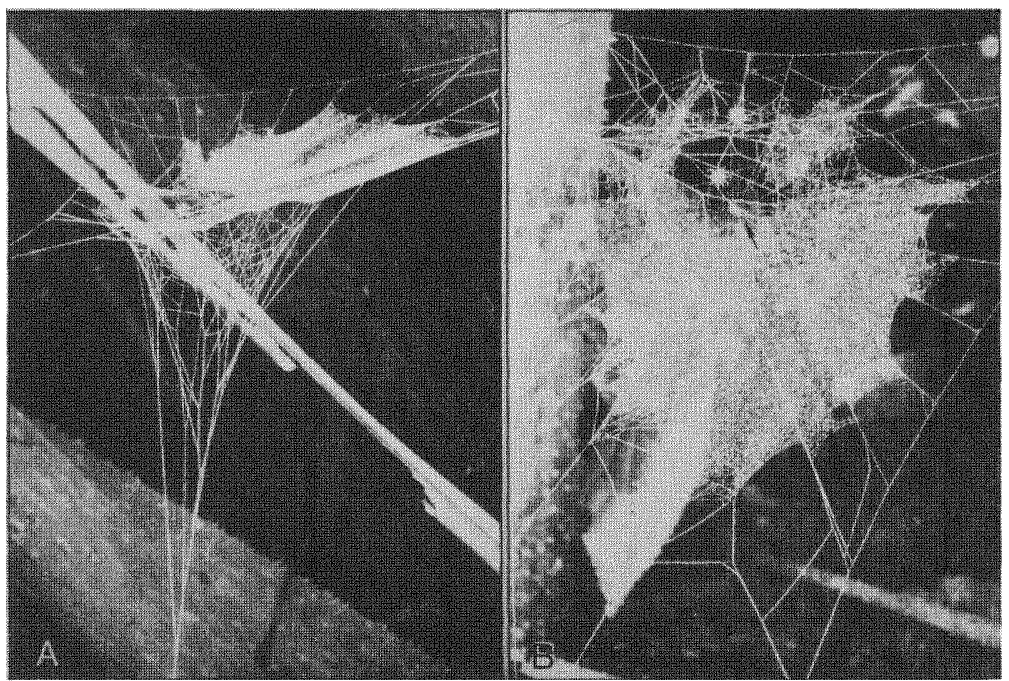

Figure 12. Conifabar parvus web. A. Side view showing framework threads, radii, mat of non-sticky spirals, and cone radii. B. Top view showing non-sticky spiral mat, two stellate eggsacs, and the female (arrow) resting at the web's hub.

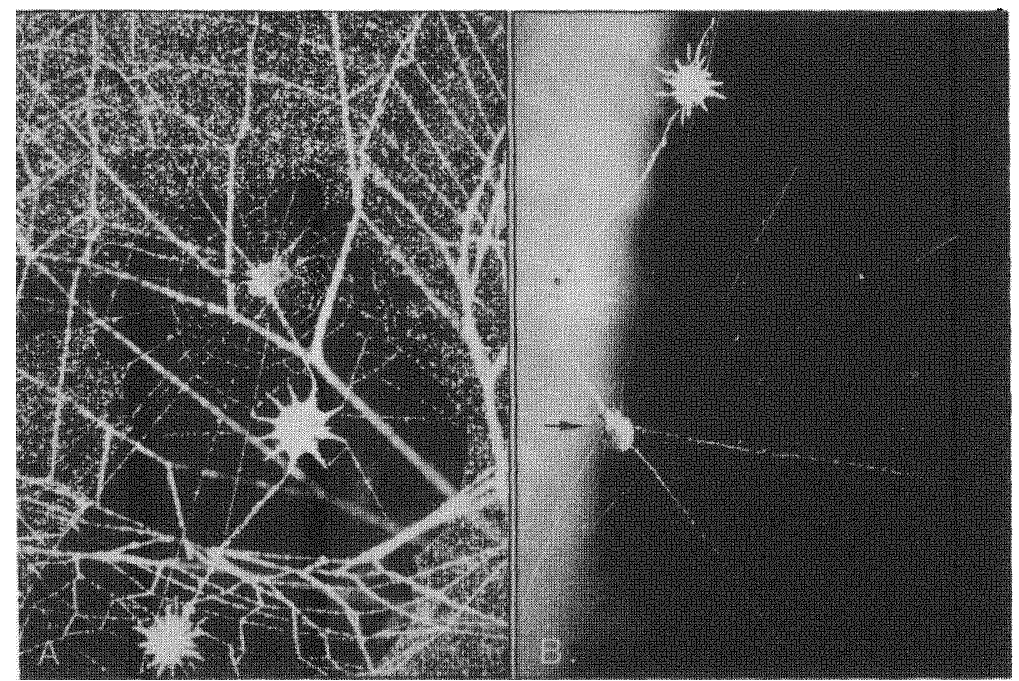

Figure 13. Conifaber parvus web hub and eggsacs. A. Female (arrow) restıng at hub. Two stellate eggsacs and some of the horizontal web's fine, non-sticky threads are visible. B. Female (arrow) resting in crouched posture at the hub of a web decorated with linear stabilimenta. 
the mesh is a cone-shaped, rudimentary orb with no sticky spiral. The Robinsons attributed a defensive function to these structures, and indeed the arguments developed here suggest that barrier meshes made by a number of other araneids (Metepeira, Leucauge, Argiope, Arachnura, Gasteracantha, and Phonognatha) may also function defensively.

The evolutionary origin of the orb-plus-cone web designs in uloborids is not clear. At least two other uloborid orb-plus-cone webs are known. Workman (1896) described the orb-plus-cone web of Uloborus quadrituberculatus (Thorell). His apparently schematic drawing shows a horizontal orb lacking spiral lines and a cone with a 14 loop spiral (he did not note whether or not the spiral was sticky). The cone is attached on all sides to surrounding vegetation by short lines. In Sembrong Jungle near Layang-Layang, Johore, Malaya, Frances Murphy photographed the orb-plus-cone web of a specimen matching Workman's (1896) description of $U$. quadrituberculatus. This web was constructed about $1.5 \mathrm{~m}$ above the ground and had a zigzag outer loop and an irregular cone spiral. An unidentified species of Tangaroa collected in mesophyll rainforest in the Iron Range, northeastern Queensland, Australia had an orb-plus cone web with a zigzag outer loop of rim sticky spiral (V. Todd Davies, personal communication). It is not known if the cone spiral was sticky. However, a small, unidentified Tangaroa species from Yap, Caroline Islands constructed a horizontal orb-web in both the field and lab (Joseph Beatty and James Berry, personal communication and BDO unpublished observations, respectively), indicating that the cone-web is not characteristic of all members of this most primitive uloborid genus (Opell, 1979) and, therefore, does not represent the "original" uloborid web design.

We do not know if the cones of the five species studied here are constructed in the same manner. Certain behaviors associated with cone construction in $U$. conus (and probably $U$. albolineatus and $U$. bispiralis) including the laying of a jagged sticky spiral with few attachments to the radii, formation of a cone by cutting and reattaching radii to a central line, replacement and reposition of radii, and pulling the orb into a cone, have not been seen in other uloborids. When one takes into account the webs of other uloborids such as Philoponella vicina (Peters 1953, 1955), P. semiplumosa (Lahmann and Eberhard 1979), P. oweni (Eberhard 1969), P. divisa (Opell 1979), and $P$. para (Eberhard, unpub.) which are more or less 
reduced and modified planar or domed orbs in the midst of meshes which include sticky as well as non-sticky threads ( $P$. oweni also spins orbs without meshes-Eberhard, 1969), the "orb" of Polenecia (=Sybota) which lacks sticky spirals and has instead sticky radii (Wiehle 1931), the orbs cum sheet webs spun by young spiderlings and mature males of several species (Szlep, 1961; Eberhard, 1977b), and the various simplified webs of Hyptiotes (Wiehle 1927, Marples and Marples 1937) and Miagrammopes (Akermann 1932, Lubin et al. 1978), it becomes clear that there is an extraordinary diversity of web forms in the relatively small family Uloboridae. It is likely that, in conjunction with morphological studies, a fuller understanding of the webs and behavior of uloborids will shed more light on relationships within the family.

\section{Systematic Section \\ Conifaber new genus* \\ Figures 14-15, 20-29}

Type. The type species of Conifaber is Conifaber parvus, new species. The genus name is a masculine noun derived from the Latin nouns conus and faber and means "cone craftsman".

Diagnosis. Conifaber contains the smallest known uloborids, females being $2.0 \mathrm{~mm}$ and males $1.5 \mathrm{~mm}$ long. Because of their small size members of this genus are more likely to be confused with those of Ariston and Siratoba than with Zosis, Octonoba, and Purumitra, to which they are more closely related. Conifaber males and females are distinguished from those of Ariston and Siratoba (Opell, 1979; figs. 41,72 ) by having a strongly recurved anterior eye row whose median eyes are located on a slight anterior carapace extension and have a diameter twice that of the other eyes (Figs. 20-23). Unlike Ariston and Siratoba females whose first femora are 1.5 and 2.0 times the carapace length, respectively, and whose thoracic grooves are in the carapace's posterior two-fifths, Conifaber females have first femora equal in length to the carapace and have a centrally located thoracic groove. Like Ariston, but unlike Siratoba, Coni-

*For nomenclatural purposes B. D. Opell is the author of the genus Conifaber and the species $C$. parvus. 
faber females lack dorsal abdominal tubercles. Like Siratoba but unlike Ariston, their clypeus height in anterior view is equal to the AME diameter. Conifaber males lack first femoral macrosetae present in Ariston and Siratoba males (Opell, 1979, figs. 39, 70) and, like Ariston, lack abdominal tubercles.

Using Opell's (1979) keys to uloborid genera, Conifaber males key to couplet 10, which separates Octonoba and Purumitra, and females key to couplet 10, which separates Octonoba and Uloborus. Conifaber males are distinguished from those of Octonoba and Purumitra by having first femora whose lengths are equal to rather than 1.5 to 2.0 times as long as the carapace, by lacking femoral macrosetae present in these genera (Opell, 1979; figs. 181, 183), and by having a longer, more conspicuous tegular spur than these genera (Fig. 14; Opell, 1979; plate 6-c, fig. 157). Conifaber females lack dorsal abdominal tubercles present in Octonoba and Uloborus (Opell, 1979; figs. 132, 140) and have inconspicuous, anteriorly directed epigynal lobes (Figs. 24-26) instead of conspicuous posteriorly directed lateral epigynal lobes (Opell, 1979; figs. 137, 145, 178, 184).

Description. Maximum carapace width 0.84 carapace length, attained in posterior half of female carapace and in posterior third of male carapace (Figs. 21-22). Female carapace slopes up to a point just behind PLE and then down to AME (Fig. 20). Male carapace slopes more steeply up to a point slightly forward of its center and then down to PME (Fig. 23). Shallow, transverse female thoracic groove at carapace center; deep, U-shaped male thoracic groove in posterior quarter of carapace. In both sexes anterior eye row strongly recurved so that a line across AME's posterior margins passes in front of ALE's by a distance equal to one ALE diameter. Posterior eye row slightly recurved so that a line across PME's posterior margins passes along PLE's anterior margins. Median ocular area's length and posterior width 0.8 its anterior width. Female AME diameter 0.75 that of male AME, remaining eyes equal to 0.66 female AME and 0.50 male AME. AME's 1.3 as far from one another as from ALE's, PME's 1.7 as far from one another as from PLE's. Sternum 0.80 as wide as long, widest between first and second coxae. Female endite 0.80 and male endite 1.00 as wide as long. Labium 1.40 as wide as long. First femur equal in length to carapace. Male first tibia with six or seven short and one long 

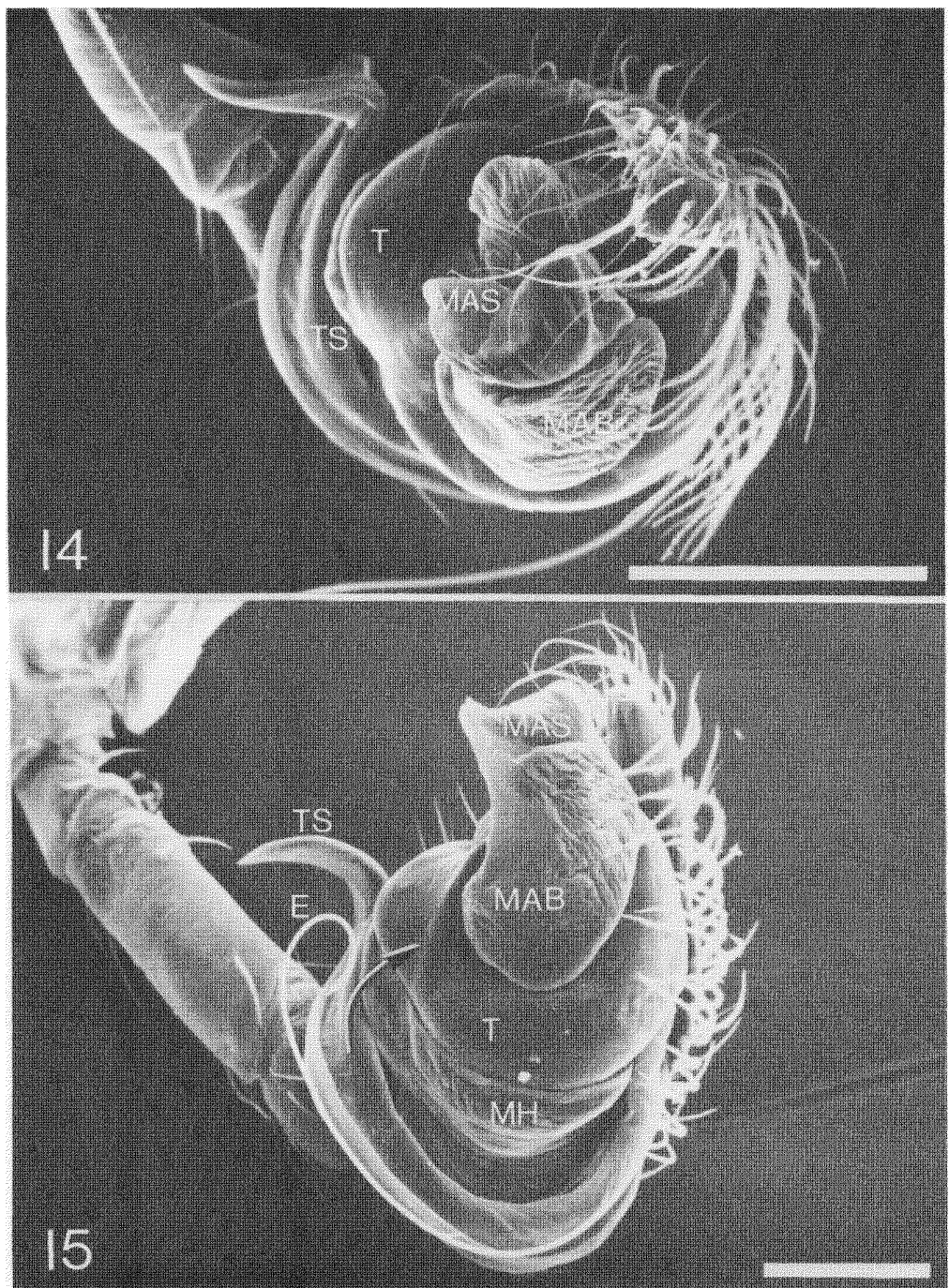

Figures 14 and 15. Apical (14) and retrolateral (15) views of Conifaber parvus n. sp. holotype male left palpus. The arrow in 15 shows the normal position of the tegular spur (TS) embolus (E) guide as it rests in the grooved tegulum (T). MAB = median apophysis bulb, MAS = median apophysis spur, $\mathrm{MH}=$ middle hematodocha. Scale lines are $100 \mu \mathrm{m}$ long. 
dorsoprolateral macrosetae, two or three long proximodorsal macrosetae, and two or three distoretrolateral macrosetae (Fig. 28). Abdomen without tubercles or abrupt peak (Figs. 20-23). Female abdomen 0.98 as wide and 1.38 as high as long, male abdomen 0.70 as wide and 0.93 as high as long. Distance between cribellum and epigastric furrow 0.44 abdomen length. Abdomen and cephalothorax were separated when the epigynum was removed. Examination of the severed petiole revealed no large tracheal trunks, indicating that, as in Philoponella and Daramuliana (Opell, 1979 fig. 1), no tracheae extend into the cephalothorax or, as in Zosis, Purumitra, and Octonoba (Opell, 1979; fig. 2), only fine tracheoles extend into the cephalothorax.

Male Palpus. Femur without ventral tubercles. Like Zosis, Purumitra and Octonoba (Opell, 1979; plates 6-c,d, 7-c,d, fig. 157), Conifaber male palpi have a tegular spur which acts as an embolus guide (Figs. 14-15). This tegular spur is proportionately larger than those of other genera and rests in a tegular groove unique to Conifaber. Members of Zosis also have a large, grooved tegular spur, but the median apophysis bulb of Conifaber is a plate rather than a hemisphere, and its median apophysis spur a grooved plate rather than a hook. The tegular spur's tip may rest in the median apopysis spur's distal groove.

Epigynum. Two posterior lateral epigynal lobes extend anteriorly a short distance, concealing a pair of weakly sclerotized, anteriorly directed oval areas (Figs. 24-25). In posterior view the epigynum's posterior plate is 0.6 as high as broad and has slightly curved and rounded ventral rim about one third the height of the posterior plate (Fig. 26). A highly coiled duct leads from each weakly sclerotized oval to a spherical spermatheca whose short fertilization duct appears to connect to the vagina's ventrolateral margin (Fig. 27).

Distribution. This genus is known only from the type localities in eastern central Colombia.

Conifaber parvus new species

Figures 14-15, 20-29

Types. Male holotype, male paratype, and female paratype from Finca Mozambique, $15 \mathrm{~km} \mathrm{S.W.} \mathrm{of} \mathrm{Puerto} \mathrm{Lopez} \mathrm{in} \mathrm{the}$ 
Colombian department of Meta; collected 1978 by W. G. Eberhard, in the Museum of Comparative Zoology. The specific epithet is a Latin noun in apposition, referring to the small size of members of this species.

Description. As most features of this species are presented in the genus description, only those of color and size are given here. Total length of female $1.92 \mathrm{~mm}$, of males $1.50 \mathrm{~mm}$. Female carapace 0.72 $\mathrm{mm}$ long, male carapace $0.66 \mathrm{~mm}$ long. Female sternum $0.44 \mathrm{~mm}$ long, male sternum $0.38 \mathrm{~mm}$ long. Female AME diameter $60 \mu \mathrm{m}$, male AME diameter $80 \mu \mathrm{m}$, remaining eyes of both sexes $40 \mu \mathrm{m}$ in diameter. Female leg length (I-IV): 2.86, 1.78, 1.52, $2.42 \mathrm{~mm}$. Male leg length: $2.70,1.56,1.33,1.94 \mathrm{~mm}$. Female calamistrum composed of 10 setae and $0.22 \mathrm{~mm}$ long, extending 0.52 the metatarsus length. Female cribellum $180 \mu \mathrm{m}$ wide, $60 \mu \mathrm{m}$ long. Female anterior spinnerets $0.30 \mathrm{~mm}$ long, male $0.16 \mathrm{~mm}$ long. Female posterior spinnerets 0.27 long, male $0.18 \mathrm{~mm}$ long. Female anal tubercle 0.14 $\mathrm{mm}$ long, male $0.10 \mathrm{~mm}$ long.

Except for dark circles around the eyes (Figs. 21-22) members of neither sex have conspicuous color markings. The thoracic groove is slightly darker than the rest of the carapace, and white guanine deposits under the abdomen's integument are interrupted by the cardiac area which creates a tan median stripe (Figs. 21-22). Lacking these deposits, the anterior third of the female's abdomen is also tan rather than white.

Distribution. Known only from the type locality in eastern central Colombia.

\section{Uloborus conus new species*}

Figures 16-19, 30-35

Types: All types from Papua New Guinea. Female holotype and paratype from Madang Prov., $40 \mathrm{~km}$ south of Madang, collected 21 March 1979 by H. W. Levi and Y. D. Lubin. Two male and three female paratypes from Morobe Prov., Buso Forest Reserve, collected 25 Oct. 1979 by Y. D. Lubin. Four female paratypes from

*For nomenclatural purposes B. D. Opell is the author of this species. 

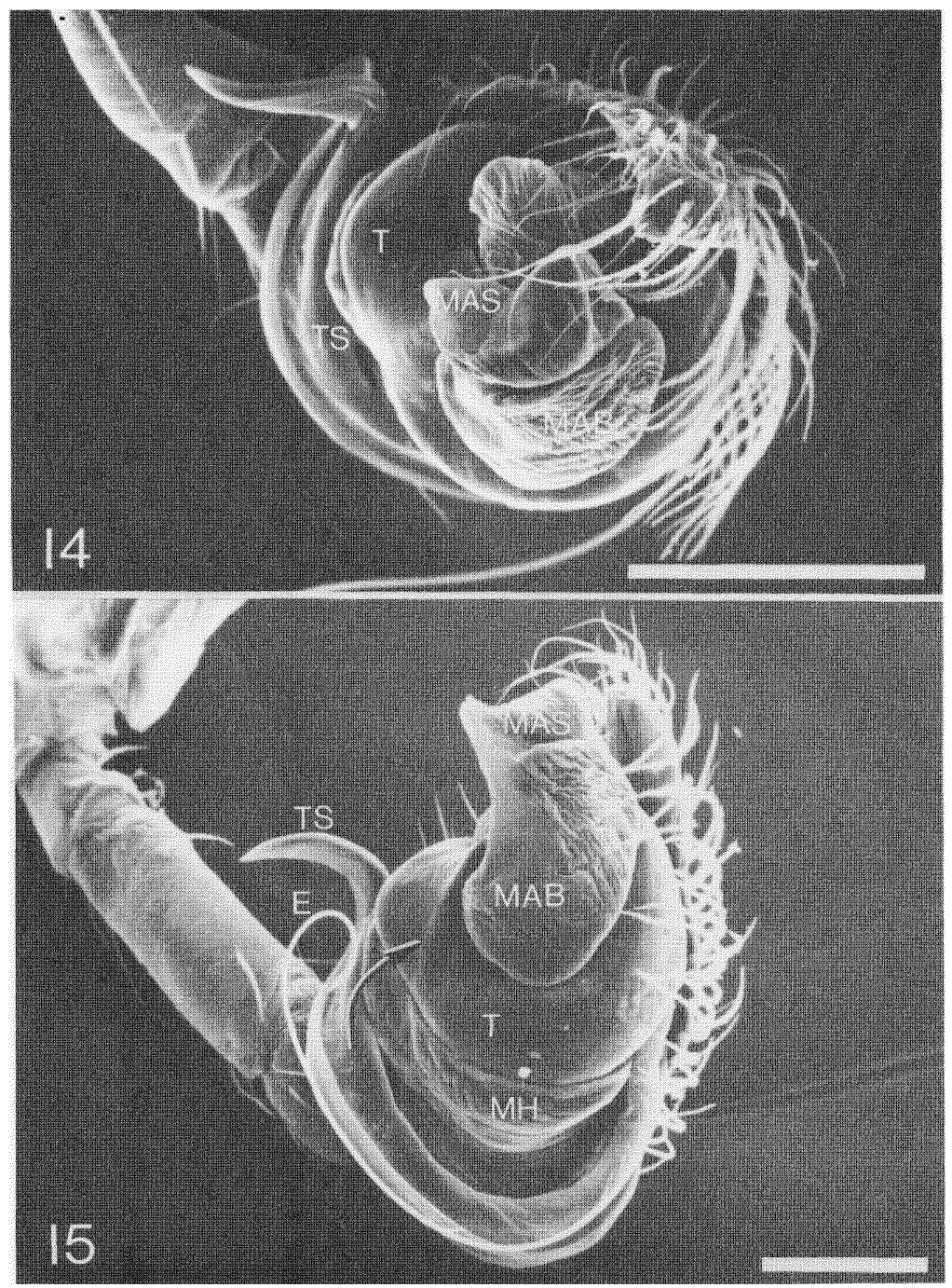

Figures 16-19. Uloborus conus $\mathrm{n}$. sp. 16. Retrolateral view of holotype rnale left palpus (a trilobed piece of debris is lodged at the upper right). 17. Retrolateral view of MAS. 18. Apical view of MAS. 19. Ventral view of female paratype epigynum. $C=$ conductor; other abbreviations as in Figures 14 and 15. Scale lines are 100 $\mu \mathrm{m}$ long. 
Central Prov., along Brown River, near Port Moresby, collected 29 April 1980 by Y. D. Lubin. One male and one female paratype deposited in the American Museum of Natural History, the remaining types are deposited in the Museum of Comparative Zoology. The specific epithet is a Latin noun in apposition, referring to the conical web produced by members of this species.

Diagnosis. Males and females are distinguished by a carapace length of less than 1.00 and $1.30 \mathrm{~mm}$, respectively. Males have a long, lobed palpal femoral tubercle, a reduced, flattened median apophysis, a long, broad conductor, and a blunt median apophysis spur (Figs. 16-18). Length of female femur I less than 1.2 carapace length rather than 1.4-1.5 carapace length as in other uloborids. Central region of epigynum from which lobes arise about one third rather than half as wide as the posterior plate (Figs. 19, 34).

Description. Female. Total length 2.80-3.40 $\mathrm{mm}(\mathrm{X}=3.20)$, carapace length $1.00-1.30 \mathrm{~mm}(\mathrm{X}=1.09)$, maximum carapace width 0.90-1.00 $(X=0.96)$, carapace width at PLE's 0.58-0.64 $\mathrm{mm}(\mathrm{X}=$ $0.60)$, area. All eyes except AME's surrounded by small black circles (Fig. 30). PLE nearer midline than in other Uloborus species. Sternum tan. Leg I of most specimens as shown in Fig. 33, but nearly black in two dark specimens. Dorsum of femur $I$ of all specimens black. Abdomen of most specimens light tan or white. Abdomen of two dark specimens with white dorsum, black venter and two broad, white lateral stripes extending from anterior apex to posterior tips. Epigynum consists of two small, weakly sclerotized posterior lobes (Fig. 19) whose combined basal width is one-third that of the posterior plate (Fig. 34). An epigynal opening found dorsal to each lobe leads to a large, irregular spermatheca from whose posterior lateral margin a short fertilization duct extends (Fig. 35).

Male. Total length $2.00-2.20 \mathrm{~mm}$, carapace length $1.00 \mathrm{~mm}$, maximum carapace length $0.85 \mathrm{~mm}$, carapace width at PLE's 0.66 $\mathrm{mm}$, sternum length $0.56 \mathrm{~mm}$. Carapace and sternum coloration similar to that of female except that broad gray streaks extend anteriorly from the posterior eyes (Fig. 31). Legs light tan, tibiae II-IV with light gray dorsal tip. Femur I with three prolateral, one dorsal, central; and one distal, retrolateral macrosetae (Fig. 32). 

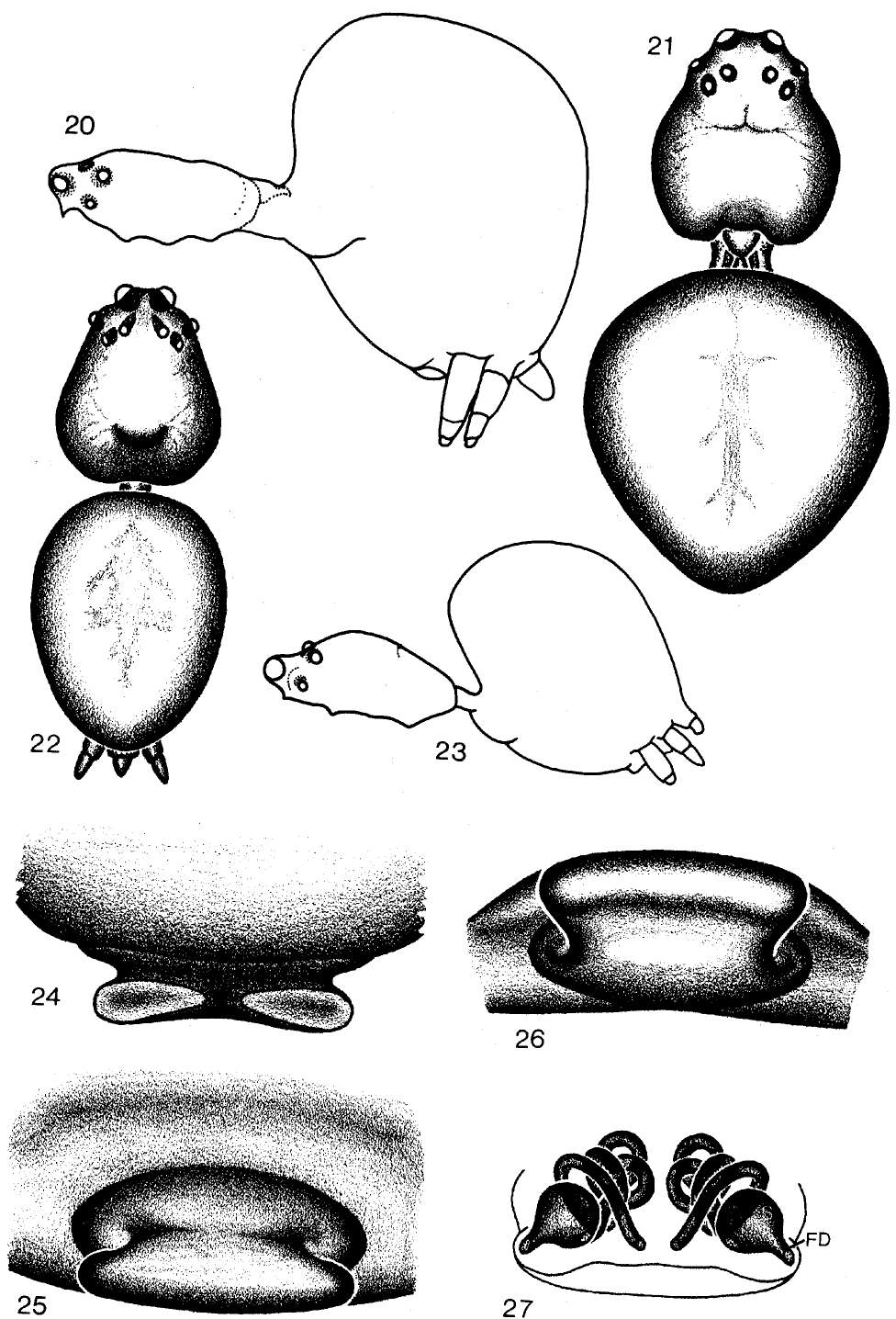

26

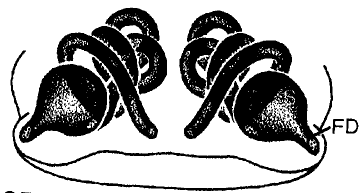

27

Figures 20-27. Conifaber parvus n. sp. 20. Lateral view of female. 21. Dorsal view of female. 22. Dorsal view of male. 23. Lateral view of male. 24. Anterior view of epigynum. 25. Ventral view of epigynum. 26. Posterior view of epigynum. $C=$ conductor, $D=$ other abbreviations as in Figures 14 and 15. Scale lines are $100 \mu \mathrm{m}$ long. 
Tibia I with eight prolateral, seven dorsal, and three retrolateral macrosetae. Sternum and abdominal venter with orange setae. Abdomen gray with a pair of thin, white, lateral longitudinal stripes running nearly its full length. Palpal femur with a large, lobed retrolateral tubercle and a very small prolateral tubercle (Fig. 16). Median apophysis bulb small and flattened (Fig. 16); median apophysis rectangular with a blunt apex (Figs. 17-18). Conductor long and broad, extending from median apophysis spur to area of palp adjacent to patella.

Distribution. Known only from the type localities in Papua New Guinea.

\section{Uloborus albolineatus new species*}

Figures 36-39.

Type. Female holotype from Lowlands Agricultural Experimental Station, Kerevat, East New Britain, Papua New Guinea, collected 6 July 1980 by Y. D. Lubin, deposited in the Museum of Comparative Zoology. The specific epithet is a noun in apposition, referring to the species' white median abdominal stripe.

Diagnosis. Males are unknown. The female is distinguished by having reddish brown median eyes, a very convex sternum (Fig. 37), white guanine deposits in the cardiac region (Fig. 36), and weakly sclerotized epigynal lobes rising from the center rather than posterior of a transparent epigynum (Fig. 38). Unlike many Uloborus species, the carapace lacks a conspicuous median light stripe.

Description. Female. Total length $2.40 \mathrm{~mm}$, carapace length 0.92 $\mathrm{mm}$. maximum carapace width $0.74 \mathrm{~mm}$, carapace width at PLE's $0.50 \mathrm{~mm}$. Carapace tan with gray, reticulate lateral markings (Fig. 36). Median eyes reddish brown. AME's on a more conspicuous tubercle than most Uloborus species. Sternum tan, widest at coxae I rather than between coxae I and II as in other Uloborus species. Legs light tan with faint gray distal rings on most segments. Tibia I with very sparse distal setal brush. Abdomen height and width 0.9 its length, dorsum with a pair of centrolateral tubercles, posterior

\footnotetext{
*For nomenclatural purposes, B. D. Opell is author of this species.
} 

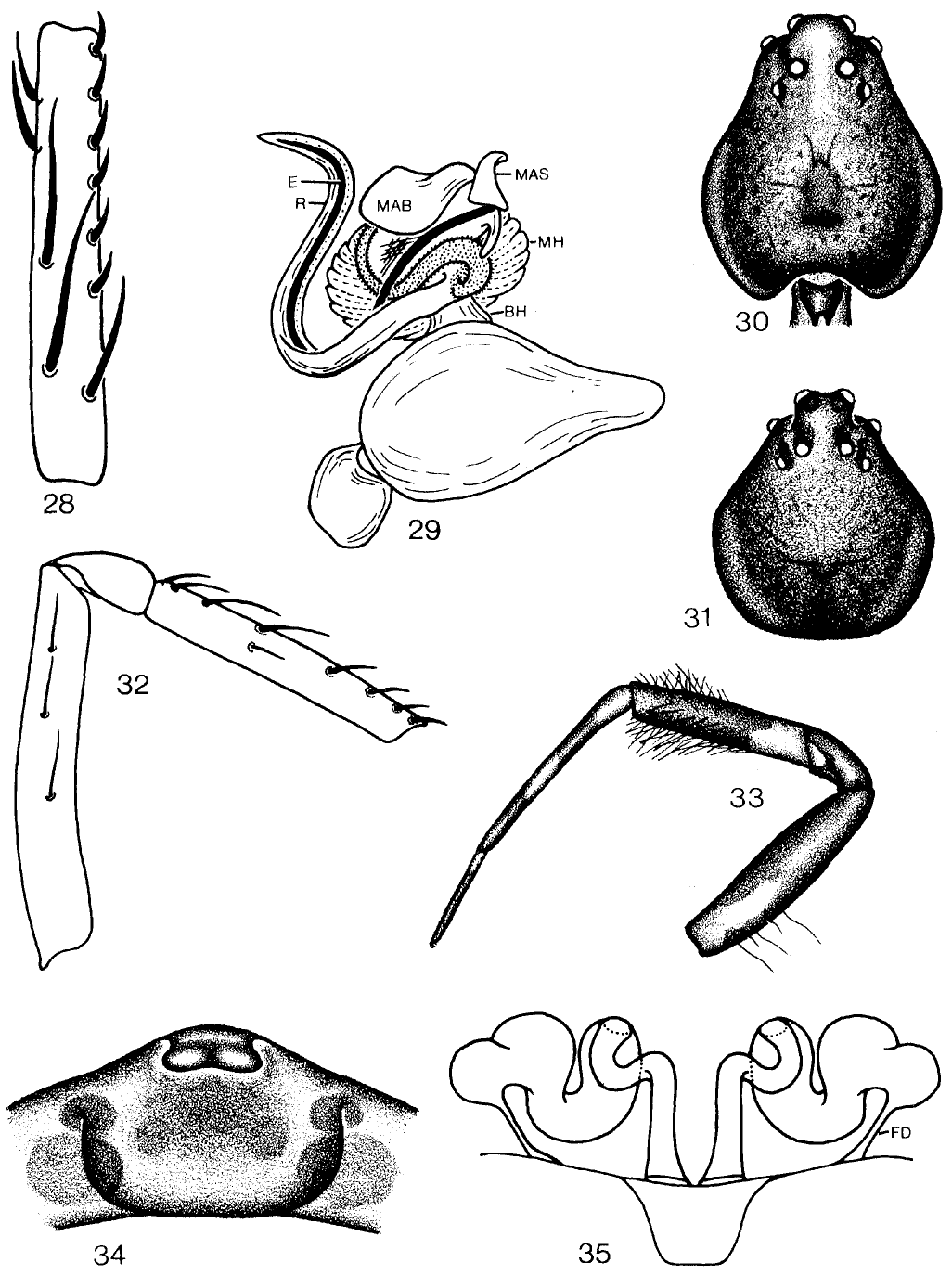
tip projecting slightly posterior to anal tubercle's base and separated from anal tubercle by a distance one third the abdomen's height. White guanine deposits extend both in a narrow transverse band across the abdomen's anterior ventral surface and along the cardiac area. A broader, more diffuse median guanine deposit extends from the abdomen's humps to its posterior tip. A pair of large guanine spots is found anteriolaterally to the spinnerets. Epigynum convex with broad posterior extension, a pair of low, weakly sclerotized median lobes, and a transparent integument through which a single pair of spherical spermathecae is clearly visible (Figs. 38, 39).

Distribution. Known only from the type locality in Papua New Guinea.

\section{Uloborus bispiralis new species*}

Figures $40-48$.

Types: Female holotype, three male and seven female paratypes from Lowlands Agricultural Experimental Station at Kerevat, East New Britian Prov., collected 2, 4, and 6 July 1980 by Y. D. Lubin. Male and two female paratypes deposited in the American Museum of Natural History, remaining types in the Museum of Comparative Zoology. The specific epithet is a latin noun in apposition, referring to the male's doubly coiled embolus.

Diagnosis. Females are distinguished by having a single, narrow median, posterior epigynal lobe (Figs. 42, 43) rather than a pair of posterior epigynal lobes, and by each epigynal duct making five rather than the usual single loop (Fig. 44). Males are distinguished by an embolus which loops twice rather than once around the

*For nomenclatural purposes B. D. Opell is the author of this species.

Figures 28 and 29. Conifaber parvus n. sp. 28. Dorsal view of male left first tibia. 29. Retrolateral view of expanded male left palpus $(\mathrm{R}=\operatorname{radix}, \mathbf{B H}=$ basal hematodocha, other abbreviations as in Figs. 14 and 15).

Figures 30-35. Uloborus conus n. sp. 30. Dorsal view of female carapace. 31. Dorsal view of male carapace. 32. Prolateral view of male first femur, patella, and tibia. 33. Retrolateral view of female leg I. 34. Posterior view of epigynum. 35. Dorsal view of cleared epigynum. 


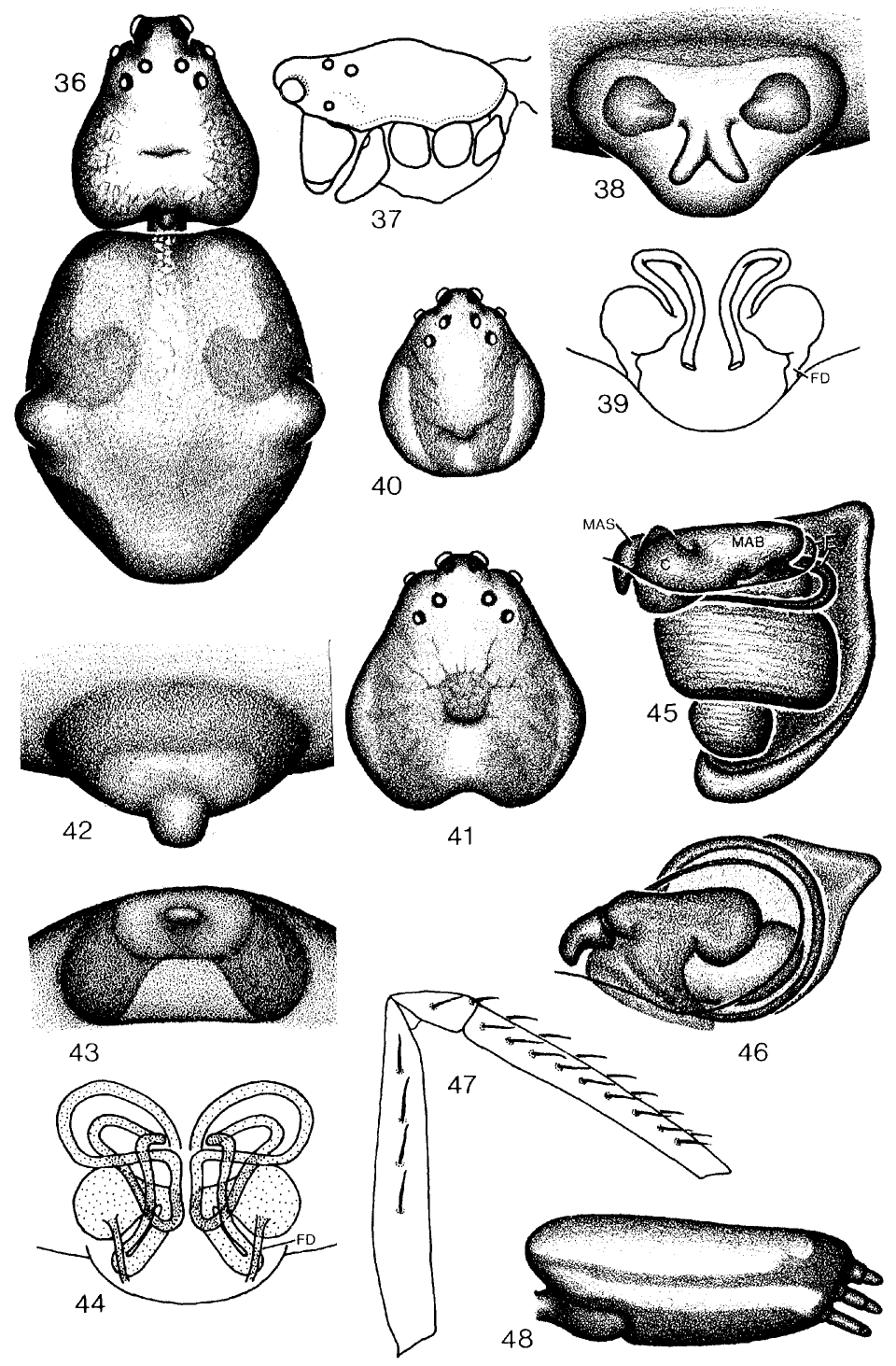


median apophysis and by a flattened, elongate median apophysis bulb which bears a broad conductor (Figs. 45, 46). Both males and females have a gray lateral abdominal stripe (Fig. 48).

Description. Female. Total length $3.28-3.68 \mathrm{~mm}(\mathrm{X}=3.47, \mathrm{~S}$, $0.14, \mathrm{~N}=8)$, carapace length $1.10-1.20 \mathrm{~mm}(\mathrm{X}=1.15, \mathrm{SD}=0.04)$, maximum carapace width $0.94-1.04(X=0.98$, SD 0.04$)$, carapace width at PME's $0.54-0.58 \mathrm{~mm}(\mathrm{X}=0.56$, SD 0.01). All eyes except AME's surrounded by small black circles (Fig. 41). Carapace with light lateral margins, light posterior median stripe, and central gray patch. Sternum tan. First and second legs light gray with tan proximal ring on tibia, metatarsus, and tarsus. Tibia I without a conspicuous setal brush. Third and fourth legs tan with gray distal rings on tibia, metatarsus, and tarsus. Abdomen without humps, dorsal and lateral surfaces densely covered by white guanine spots except in cardiac region and along a faint lateral stripe similar to but not as sharply defined as that shown in Fig. 48. Venter tan with only sparse guanine spots. Epigynum a raised mound with single median lobe (Figs. 42, 43), probably representing a pair of fused lateral lobes. Under normal light microscopy a clove oil-cleared epigynum showed only a pair of oval spermathecae with a fertilization duct leading from the posterior lateral margin of each and a short, broad duct extending from the median surface of each to epigynum's posterior margin. Examination with Nomarski optics revealed the more extensive system of thin-walled ducts shown in Figure 44. It was not possible to determine precisely where the ducts opened externally, but this appears to be between the spermathecae and near the base of the epigynal lobe.

Male. Total length $2.32-2.40 \mathrm{~mm}$, carapace length $0.98-1.00 \mathrm{~mm}$, maximum carapace width $0.78-0.80 \mathrm{~mm}$, carapace width at PLE's $0.50-0.52 \mathrm{~mm}$. Carapace and sternum coloration similar to that of

Figures 36-39. Uloborus albolineatus n. sp. 36. Dorsal view of female holotype. 37. Lateral view of female carapace. 38. Ventral view of epigynum. 39. Dorsal view of cleared epigynum.

Figures 40-48. Uloborus bispiralis n. sp. 40. Male carapace. 41. Female holotype carapace. 42. Ventral view of holotype epigynum. 43. Posterior view of epigynum. 44. Dorsal view of cleared epigynum. 45. Retrolateral view of male palpus. 46. Apical view of male palpus. 47. Prolateral view of male first femur, patella, and tibia. 48. Lateral view of male abdomen. 
females except for absence of central gray carapace spot (Fig. 40). Legs reddish brown. Femur I with three or four prolateral macrosetae, tibia I with nine prolateral, six or seven dorsal, and three retrolateral macrosetae (Fig. 47). Abdomen with fewer guanine spots than female, dorsum and lateral surface tan; gray lateral stripe, gray venter and gray posterior tip (Fig. 48). Palpal femur with a large proximal retrolateral tubercle and small prolateral tubercle. Median apophysis bulb flat and elongate $(0.16 \mathrm{~mm}$ long), terminating in a bent median apophysis spur (Figs. 46, 47). Unlike other members of the genus, the embolus loops twice around the median apophysis bulb before passing into a broad, weakly sclerotized conductor.

Distribution. Known only from the type locality in Papua New Guinea.

\section{ACKNOWLEDGEMENTS}

YDL and HWL thank the Wau Ecology Institute for use of the facilities in Wau, and S. Smith for making available the facilities at LAES (Kerevat). A portion of this study was supported by a Smithsonian Institute Scholarly Studies Research Award (to M. H. Robinson and YDL). A Small Projects Grant from the College of Arts and Sciences, Virginia Polytechnic Inst. and State Univ. (to BDO) made the S.E.M. work possible. WGE thanks Carlos Rodrigues, the Dixon Stroud family, Dr. Luis Arango, Dr. Madhav Gadgil, and A. J. T. Johnsingh for help and hospitality in the field and the Comité de Investigaciones of the Universidad del Valle, Cali, Colombia and the Vicerectoría de Investigaciones of the Universidad de Costa Rica for financial support. HWL thanks National Science Foundation grant DEB 76-15568 and DEB 79-23004 for support and M. H. Robinson and B. Robinson for being instrumental in getting him to New Guinea and flavoring his stay with their hospitality and enthusiasm. We thank Frances Murphy, V. Todd Davies, Joseph Beatty and James Berry for allowing us to use their unpublished observations and $\mathrm{M}$. $\mathrm{H}$. Robinson and B. Robinson for their comments on and criticism of the manuscript. 


\section{Literature Cited}

ACKermann, C.

1932. On the spider Miagrammopes sp. which constructs a single-line snare. Ann. Natal mus. 7:137-143.

CARICO, J. E.

1977. A simple device for coating orb webs for field photography. Bull. Br. arachnol. Soc. 4:100.

EberhaRd, W. G.

1969. The spider Uloborus diversus Marx and its web. PhD. thesis, Harvard Univ.

1972. The web of Uloborus diversus (Araneae: Uloboridae). J. Zool., Lond. 166:417-465.

1977a. Photography of orb webs in the field. Bull. Br. arachnol. Soc. 3(7):200-204.

1977b. The webs of newly emerged Uloborus diversus and of a male Uloborus sp. (Araneae: Uloboridae). J. Arachnol. 4:201-206.

1981. Construction behaviour and the distribution of tensions in orb webs. Bull. Br. arachnol. Soc. 5(5):189-204.

LahmanN, E. AND W. G. Eberhard

1979. Factores selectivos que afectan la tendencia a agruparse en la araña colonial Philoponella semiplumosa (Araneae: Uloboridae). Rev. Biol. Trop. 27(2):231-240.

LeGuelte, L.

1966. Structure de la toile de Zygiella $x$-notata C. (Araignées, Argiopidae) et facteurs que régissent le comportement de l'araignée pendant la construction de la toile. Thèse. Pub. Univ. Nancy: 1-77.

Lubin, Y. D., W. G. Eberhard, and G. G. MontgomerY

1978. Webs of Miagrammopes (Araneae: Uloboridae) in the Neotropics. Psyche 85(1):1-23.

Marples, M. and B. J. Marples

1937. Notes on the spiders Hyptiotes paradoxus and Cyclosa conica. Proc. zool. Soc. Lond. Ser. A Part 3 1937:213-221.

MARPLES, B. J.

1962. Notes on the spiders of the family Uloboridae. Ann. Zool. Agra 4:1-11. OPELL, B. D.

1979. Revision of the genera and tropical American species of the spider family Uloboridae. Bull. Mus. comp. Zool. 148(10):443-549.

Peters, $\mathrm{H}$.

1953. Beiträge zur vergleichenden Ethologie und Ökologie tropischen Webspinnen. Z. Morph. Ökol. Tiere 42:278-306.

1955. Contribuciones sobre la etología y ecología comparada de las arañas tejedoras tropicales. Comm. Inst. Trop. Inv. Scient. 4:37-46. 
RoBINSON, M. H. AND B. ROBINSON

1973. Ecology and behavior of the giant wood spider Nephila maculata (Fabricius) in New Guinea. Smithson. Contrib. Zool. 149:1-76.

SZLEP, R.

1961. Developmental changes in web-spinning instinct of Uloboridae: construction of the primary-type web. Behaviour 27:60-70.

WIEHLE, $\mathrm{H}$.

1927. Beiträge zur Kenntnis des Radnetzbaues der Epeiriden, Tetragnathiden, und Uloboriden. Z. Morph. Ökol. Tiere 9:468-537.

1931. Neue Beiträge zur Kenntnis des Fanggewebes der Spinnen aus den Familien Argiopidae, Uloboridae, und Theridiidae. Z. Morph. Ökol. Tiere 22:348-400.

WORKMAN, T.

1896. Malaysian Spiders, volume I. Published by the author. Belfast. 

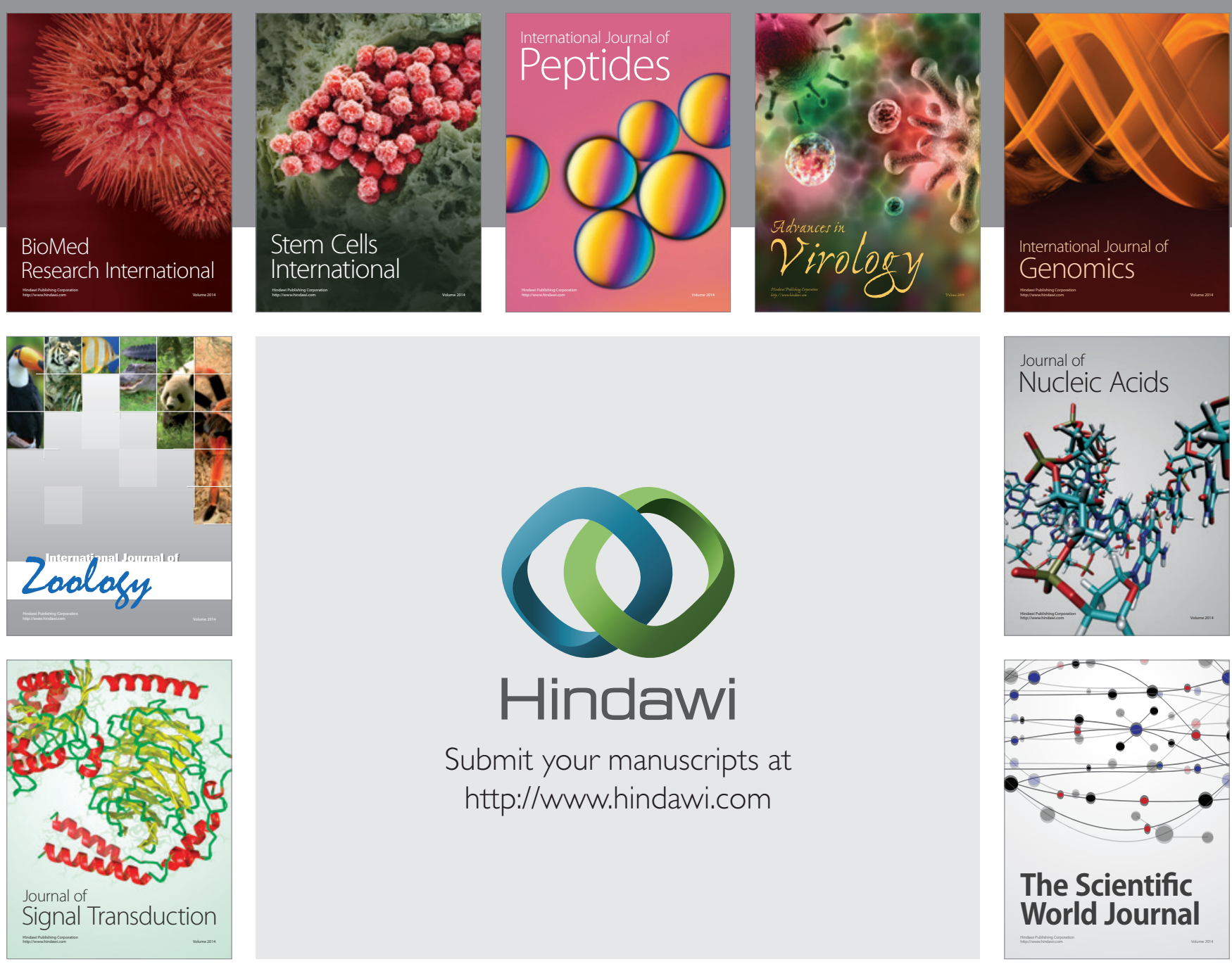

Submit your manuscripts at

http://www.hindawi.com
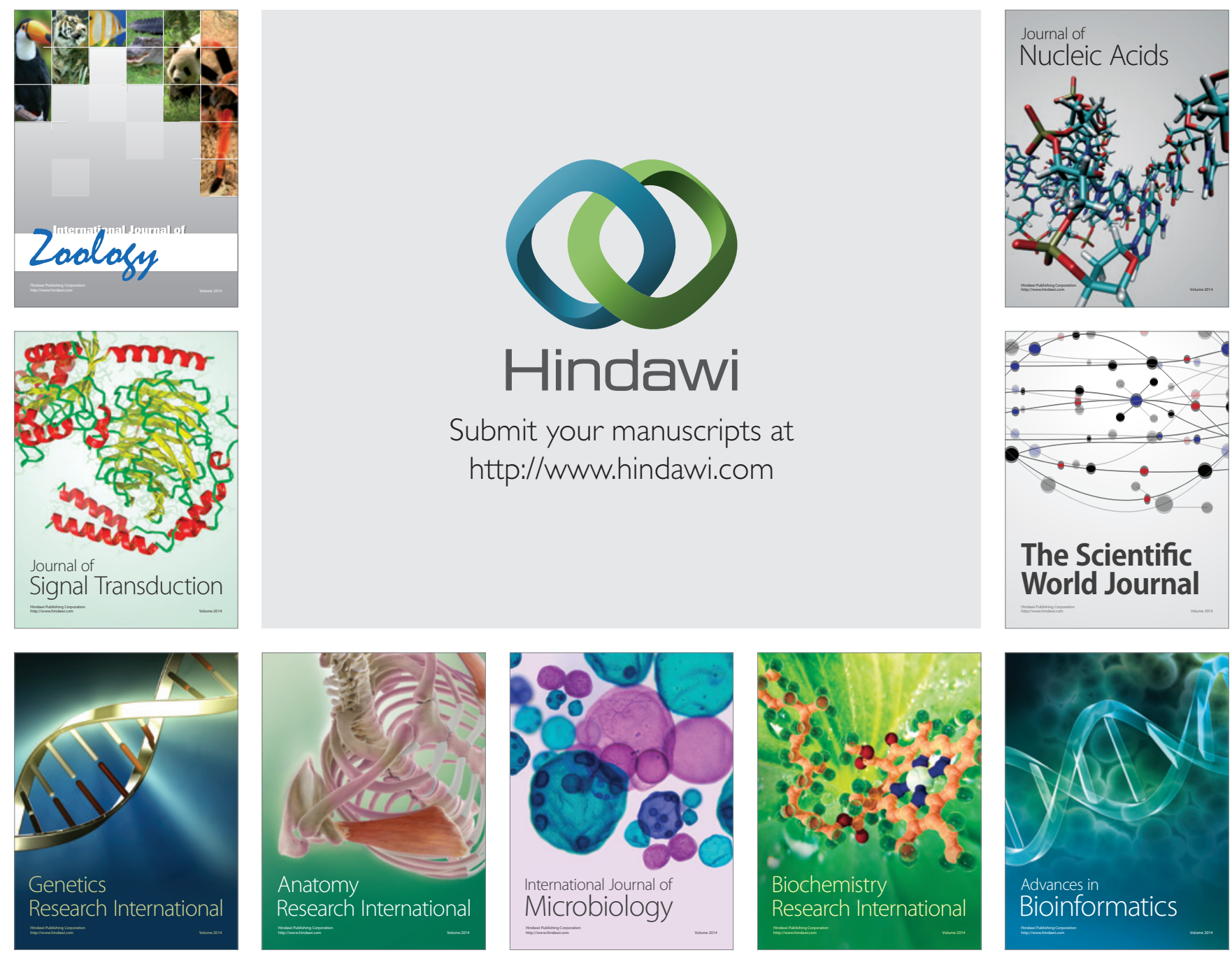

The Scientific World Journal
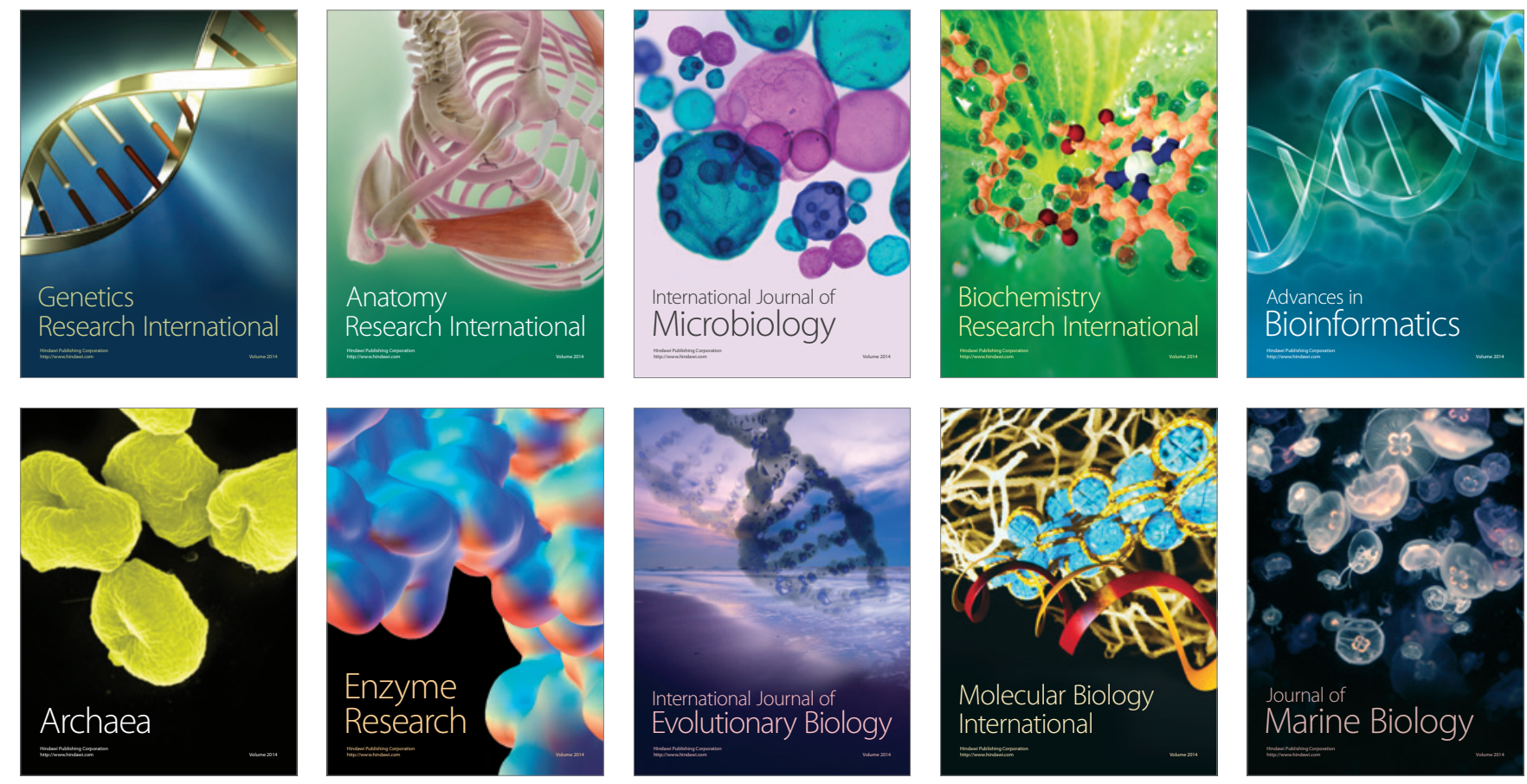